UNIVERSIDADE DE SÃO PAULO

FACULDADE DE FILOSOFIA, CIÊNCIAS E LETRAS DE RIBEIRÃO PRETO

DEPARTAMENTO DE PSICOLOGIA

LABORATÓRIO DE AVALIAÇÃO PSICOLÓGICA INFANTIL, ADULTO E FAMILIAR

Psicodinâmica familiar e características de personalidade de pais, mães e filhas obesas

Lilian Regiane de Souza Costa-Dalpino

Tese apresentada à Faculdade de Filosofia, Ciências e Letras de Ribeirão Preto da Universidade de São Paulo, como parte das exigências para a obtenção do título de Doutor em Psicologia. 
UNIVERSIDADE DE SÃO PAULO

FACULDADE DE FILOSOFIA, CIÊNCIAS E LETRAS DE RIBEIRÃO PRETO

DEPARTAMENTO DE PSICOLOGIA

LABORATÓRIO DE AVALIAÇÃO PSICOLÓGICA INFANTIL, ADULTO E FAMILIAR

\section{Psicodinâmica familiar e características de personalidade de pais, mães e filhas obesas}

\section{Lilian Regiane de Souza Costa-Dalpino}

Tese apresentada à Faculdade de Filosofia, Ciências e Letras de Ribeirão Preto da Universidade de São Paulo, como parte das exigências para a obtenção do título de Doutor em Psicologia.

Área de Concentração: Psicologia

Orientadora: Profa. Dra. Valeria Barbieri 
Autorizo a reprodução e divulgação total ou parcial deste trabalho, por qualquer meio convencional ou eletrônico, para fins de estudo e pesquisa, desde que citada a fonte.

Costa-Dalpino, Lilian Regiane de Souza

Psicodinâmica familiar e características de personalidade de pais, mães e filhas obesas. Ribeirão Preto, 2021.

355 p. : il. ; $30 \mathrm{~cm}$

Tese de Doutorado, apresentada à Faculdade de Filosofia Ciências e Letras de Ribeirão Preto/USP.

Área de concentração: Psicologia.

Orientador: Barbieri, Valeria.

1. Obesidade. 2. Relações familiares.

3. Psicodiagnóstico. 4. Psicanálise.

5. Família. 
Costa-Dalpino, Lilian Regiane de Souza

Psicodinâmica familiar e características de personalidade de pais, mães e filhas obesas

Tese apresentada à Faculdade de Filosofia, Ciências e Letras de Ribeirão Preto da Universidade de São Paulo, como parte das exigências para a obtenção do título de Doutor em Psicologia.

Aprovado em:

Banca Examinadora

Prof.(a) Instituição:

Julgamento Assinatura:

Prof.(a) Instituição:

Julgamento Assinatura:

Prof.(a) Instituição:

Julgamento Assinatura:

Prof.(a) Instituição:

Julgamento Assinatura:

Prof.(a) Instituição:

Julgamento Assinatura:

Prof.(a) Instituição: Assinatura: 
À minha filha Elisa, minha fonte mais espontânea e criativa de inspiração. 


\section{AGRADECIMENTOS}

À Profa. Dra. Valeria Barbieri, minha orientadora, que generosamente me acolheu, orientou e me inspirou com sua profunda sensibilidade e conhecimento, sempre atenta e compreensiva às minhas necessidades, expectativas e dificuldades. Minha sincera gratidão pela confiança e generosidade por me permitir fazer parte dessa pesquisa, espero que seja somente o início da nossa parceria.

Aos membros do Ambulatório de Obesidade do Hospital das Clínicas da Faculdade de Medicina de Ribeirão - USP, que permitiram e colaboraram com a realização desse estudo.

Aos colegas do Laboratório de Avalição Psicológica Infantil, Adulto e Familiar (LAPIAF- FFCLRP-USP-CNPq), pelo suporte oferecido sempre que solicitei.

Aos Prof. Dr. Álvaro José Lelé e à Profa. Dra. Deise de Matos Amparo, que, na ocasião do meu Exame de Qualificação, enriqueceram esse estudo com suas preciosas contribuições.

Ao Prof. Dr. Manoel Antônio dos Santos, por ter me aberto as portas para a pesquisa científica, orientou o meu mestrado e me inseriu no Grupo de Assistência a Transtornos Alimentares, experiências fundamentais para que eu concretizasse esse estudo.

À querida Élide Dezoti Valdanha, obrigada por ter me apresentado o projeto do qual esse estudo faz parte e, sensivelmente, ter reconhecido meus interesses.

À toda equipe de Ortopedia e Traumatologia do Hospital das Clínicas da Faculdade de Medicina de Ribeirão - USP, da qual tenho profundo orgulho de já ter feito parte, que me acolheu e me mostrou novos horizontes em momentos de dificuldades ao longo desse estudo.

À minha amiga-irmã Ana Paula Medeiros, obrigada por ter estado comigo em mais essa jornada, pelo apoio, escuta e incentivo, um dos melhores encontros que a Universidade de São Paulo me possibilitou. Que bom que o mundo pode contar com psicólogas como você!

À minha amiga Letícia De Carli Novaes, sempre preocupada e cuidadosa, obrigada por me acolher e fortelecer, principalmente no início dessa empreitada, com a vinda da Elisa, acompanhando minha gestação, literalmente, desde a descoberta, sempre me ajudando a poder conciliar estudo, com a maternidade e com o nosso trabalho na enfermaria de ortopedia.

Aos meus queridos amigos Nichollas Martins Areco e Vanessa Vaz Gomes, parceiros em momentos de trabalho, de "cafés" e de cumplicidade, que me ajudaram a encarar com mais leveza os ambivalentes sentimentos de se trabalhar diariamente em um hospital, vocês se tornaram peças cruciais para a conclusão desse estudo. 
À minha querida tia Cibele, minha amiga, mãe, ouvinte... que, por tudo isso, foi escolhida para ser a madrinha da minha filha Elisa, não poderíamos ter feito escolha melhor. Ela que tem o dom de tornar momentos tão simples em experiências únicas e cheias de afeto, obrigada por tanto.

À família do meu marido, que se tornou minha também, em especial aos meus sogros, Douglas e Eumara, que me receberam com um imenso afeto. Obrigada por tantas as vezes que me auxiliaram, principalmente por estarem com a minha filha com o mais sincero amor.

À minha cunhada Vanessa, que está sempre presente, apoiando e incentivando, com uma imensa criatividade que cativa e inspira.

Ao meu irmão Flávio, sempre generoso, sereno, parceiro e acolhedor, que me auxilia a encontrar novos ângulos de olhar o mundo.

Ao Thiago, meu companheiro, obrigada por ter estado nessa e em tantas outras jornadas ao meu lado, pelo incentivo, apoio, compreensão, paciência, cuidado, por ser incrível com nossa pequena, por me trazer segurança e amor. Obrigada por me propocionar uma exeperiência de se viver em família através de um novo ângulo.

À minha filha Elisa, obrigada por me permitir fazer parte da riqueza do seu mundo de fantasias, ele me faz relembrar que podemos ser tantas coisas, inclusive ser mãe e doutora! Obrigada por tão cedo entender meus momentos de trabalho, principalmente em um ano sem escolas, mas principalmente obrigada por aqueles nos quais eu parei tudo para estarmos juntas. Espero conseguir expressar, todos os dias, a extensão do meu amor por você.

Aos meus pais, Aparecido e Maria Inês, que me possibilitaram a existênca e desde então não medem esforço para me ampararem. Vocês partilharam desde o princípio desse sonho comigo, acreditaram na minha capacidade e me fizeram acreditar também. Quando pensei que seria impossível concluir, ofereceram novas possibilidades e me instrumentaram para encontrar soluções. Foi por conta do amor e cuidado deles por mim, que se multiplicou na relação com a minha filha, que foi possível concluir esse estudo. Meu amor incondicional, minha gratidão, minha mais profunda e sincera admiração por vocês.

A todos os meus amigos e familiares que me proporcionam momentos únicos de acolhimento, cumplicidade e descontração.

Por fim, expresso minha imensa gratidão por todas as famílias que tornaram possível esse estudo, que se dedicaram e se esforçaram para estarem presentes, agradeço pela confiança e pelos momentos extremamente enriquecedores.

Por fim, agradeço a todos aqueles que, direta ou indiretamente, participaram, apoiaram e se engajaram para a concretização desse sonho. Muito obrigada! 
Era a Chapeuzinho Amarelo. Amarelada de medo.

Tinha medo de tudo, aquela Chapeuzinho. Já não ria.

Em festa, não aparecia.

Não subia escada, nem descia.

Não estava resfriada, mas tossia.

Ouvia conto de fada, e estremecia.

Não brincava mais de nada, nem de amarelinha.

Então vivia parada, deitada, mas sem dormir, com medo de pesadelo.

Era a Chapeuzinho Amarelo...

E de todos os medos que tinha

$\mathrm{O}$ medo mais que medonho era o medo do tal do LOBO.

Um LOBO que nunca se via, que morava lá pra longe, do outro lado da montanha, num buraco da Alemanha, cheio de teia de aranha, numa terra tão estranha,

que vai ver que o tal do LOBO nem existia.

Mesmo assim a Chapeuzinho tinha cada vez mais medo do medo do medo do medo de um dia encontrar um LOBO.

Um LOBO que não existia.

E Chapeuzinho amarelo, de tanto pensar no LOBO, de tanto sonhar com LOBO, de tanto esperar o LOBO, um dia topou com ele que era assim: carão de LOBO, olhão de LOBO, jeitão de LOBO,

e principalmente um bocão

tão grande que era capaz de comer duas avós, um caçador, rei, princesa, sete panelas de arroz....

E um chapéu de sobremesa. Mas o engraçado é que, assim que encontrou o LOBO, a Chapeuzinho Amarelo

foi perdendo aquele medo: o medo do medo do medo do medo que tinha do LOBO.

Foi ficando só com um pouco de medo daquele lobo.

Depois acabou o medo e ela ficou só com o lobo.

(Chico Buarque, Chapeuzinho Amarelo) 


\section{RESUMO}

Costa-Dalpino, L. R. S. (2021). Psicodinâmica familiar e características de personalidade de pai, mãe e filhas obesas. Tese de Doutorado, Faculdade de Filosofia, Ciências e Letras de Ribeirão Preto, Universidade de São Paulo.

O aumento exponencial do número de indivíduos obesos e das graves patologias associadas à obesidade faz com que ela seja considerada um dos maiores problemas de saúde pública da atualidade. Considera-se que o desenvolvimento e manutenção do excesso de peso têm origem multifatorial. As relações familiares e a personalidade dos pais são apontadas como fatores envolvidos na etiologia desse quadro. Porém são raros os estudos que abordam aspectos psicológicos e familiares que contribuem para o surgimento da Obesidade, com a produção científica se concentrando principalmente nos componentes biológicos e nos hábitos alimentares da família. Diante dessa lacuna, o presente estudo visa contribuir para o aprofundamento da compreensão das características de personalidade na obesidade, sob o prisma da psicanálise winnicottiana. Com base nesses pressupostos, este estudo objetivou investigar, por meio de uma avaliação psicológica empregando procedimentos projetivos, as características de personalidade de pais, mães e filhas obesas e os relacionamentos que eles entretêm, buscando identificar possíveis relações entre esses elementos e o favorecimento do quadro. Participaram do estudo cinco jovens do sexo feminino, entre 12 e 25 anos, que apresentavam obesidade com IMC entre $35 \mathrm{~kg} / \mathrm{m}^{2}$ e $40 \mathrm{~kg} / \mathrm{m}^{2}$, vinculadas a um serviço de saúde pública especializado no tratamento da obesidade, e seus respectivos pais e mães. Os instrumentos utilizados para a coleta dos dados foram: (1) Roteiro de Entrevista Semiestruturada; (2) Questionnaire for Eating Disorder Diagnosis (Q-EDD); (3) Teste de Rorschach; (4) Procedimento de Desenhos de Família com Estórias (DF-E). Os dados obtidos foram analisados com base nas diretrizes dos instrumentos. Foi elaborada uma síntese psicodiagnóstica para cada um dos participantes. Posteriormente, foi realizada a articulação dos dados do pai, da mãe e da filha em cada família, resultando em uma síntese do grupo familiar. Em seguida, foi realizada uma síntese psicodiagnóstica de todas as filhas, uma de todas as mães e outra de todos pais. Finalmente, os dados dessas sínteses foram articulados em uma avaliação cruzada geral das tríades, que foram discutidos com a literatura da área. Os dados encontrados evidenciaram relações familiares marcadas pelo distanciamento afetivo. A maioria dos participantes evidenciou angústia de castração, que leva à repressão maciça das pulsões sexuais. As mães demonstraram maior controle lógico dos afetos, enquanto pais e filhas apresentaram menos sucesso nessa empreitada, o que promove a acentuação da angústia. Insatisfeitos, recorrem a defesas menos elaboradas e a integração dos afetos se torna ainda mais distante. Na busca por reequilíbrio, os pais se distanciam e usam defesas falso-self, o que dificulta o exercício da função de interdição. Jás as filhas demonstraram regressão à oralidade. As mães, ao reprimirem suas vivências afetivas, oferecem um cuidado pautado no alimento concreto. Observa-se que as filhas, numa posição regredida, apresentam uma busca voraz por amparo materno via o alimento oferecido pela mãe, enquanto a última projeta na filha suas insatisfações, criando um vínculo de dependência entre elas. A estreita relação entre mãe e filha concorda com o afastamento paterno. Dessa forma, os sintomas das filhas auxiliam toda a famíla no afastamento dos conteúdos pulsionais, sendo alimentados por todos. Os resultados revelam que a avaliação e a inclusão da família no tratamento da obesidade podem colaborar para a melhor compreensão da natureza das dificuldades psicológicas dos membros que se encontram subjacentes ao quadro da obesidade da filha.

Palavras-chave: obesidade, relações familiares, psicodiagnóstico, psicanálise, família. 


\begin{abstract}
Costa-Dalpino, L. R. S. (2021). Family psychodynamics and personality characteristics of obese fathers, mothers, and daughters. (PhD Thesis). Faculdade de Filosofia, Ciências e Letras de Ribeirão Preto, Universidade de São Paulo.
\end{abstract}

The exponential increase in the number of obese individuals and the severe pathologies associated with obesity makes it one of the greatest public health problems of today. The development and maintenance of overweight are considered to have a multifactorial origin. The etiology of this condition points to family relationships and the personality of parents as being contributing factors. However, studies addressing psychological and family aspects that contribute to the onset of Obesity are rare, with scientific production focusing mainly on biological components and eating habits of the family. Confronting this gap, this study aims to contribute to the understanding of the personality characteristics of obese girls, fathers and mothers from a Winnicottian psychoanalysis viewpoint. Based on these assumptions, this study aimed to investigate, through a psychological evaluation using projective methods, the personality characteristics of obese fathers, mothers, and daughters and the relationships they form, seeking to identify possible interactions between these elements and the support for this scenario. Five young women, between 12 and 25 years of age, who presented obesity with a BMI between $35 \mathrm{~kg} / \mathrm{m}^{2}$ and $40 \mathrm{~kg} / \mathrm{m}^{2}$, linked to a public health service specialized in the treatment of obesity, and their respective fathers and mothers participated in the study. The tools used to collect the data were: (1) Semi-structured Interview Script; (2) Questionnaire for Eating Disorder Diagnosis (Q-EDD); (3) The Rorschach Method; (4) The Drawing-ofFamily-and-Story Procedure (DF-E). Based on the data derived from the application of these tools, a psychodiagnostic synthesis was formulated for each of the participants. Subsequently, the data of the father, mother, and daughter in each family were gathered, resulting in a synthesis of the family group. Then, a psychodiagnostic synthesis of all the daughters, mothers, and fathers was produced. Finally, the data of all the families were cross-examined taking into account the literature in the area. The data found revealed family relationships marked by affective distance. Most of the participants exhibited castration anxiety, which leads to massive repression of sexual impulses. Mothers demonstrated greater logical control of affection, while fathers and daughters were less successful in this undertaking leading to the accentuation of the distress. Unsatisfied, they resort to less elaborate defenses; therefore, the integration of affections becomes even more estranged. In the search for readjustment, parents distance themselves from relationships exhibiting the use of false self defenses, which difficult the exercise of the interdiction function. While the daughters have shown regression to orality. The mothers, repressing their affective experiences, offer care based on concrete food. As observed, the daughters play a regressive role by voraciously searching for maternal support through the food offered by the mother, while the latter projects her dissatisfactions on the daughter, creating a bond of dependence between both. The close relationship between mother and daughter agrees with the father's withdrawal. Thus, the daughters' symptoms help the whole family in the repression of the drive contents, being fed by all. The results show that the evaluation and inclusion of the family in the treatment of obesity can contribute to a more thorough understanding of the nature of the psychological strain of the members underlying the context of obesity of the daughter, contributing to the elaboration of therapies more suitable to the needs of the group.

Keywords: obesity, family relations, psychodiagnosis, family, psychoanalysis. 


\section{LISTA DE TABELAS}

Tabela 1. Caracterização das famílias segundo idade, número de filhos, estado civil, coabitação dos pais, escolaridade, peso, altura e IMC filhas na ocasião da coleta.

Tabela 2. Caracterização das sessões com os participantes da Família Araújo 70

Tabela 3. Indicadores do funcionamento lógico e adaptação ao real no Teste de Rorschach de Ana

Tabela 4. Indicadores relativos ao funcionamento afetivo, segundo o método do Rorschach de Ana.

Tabela 5. Indicadores do funcionamento lógico e adaptação ao real no Teste de Rorschach de Abigail.

Tabela 6. Indicadores relativos ao funcionamento afetivo, segundo o método do Rorschach de Abigail

Tabela 7. Indicadores do funcionamento lógico e adaptação ao real no Teste de Rorschach de Altamir.

Tabela 8. Indicadores relativos ao funcionamento afetivo, segundo o método do Rorschach.de Altamir.

Tabela 9. Resumo dos principais dados obtidos nas entrevistas com as filhas.

Tabela 10. Indicadores relativos à capacidade de realização no psicograma das filhas.

Tabela 11. Avaliação da capacidade de realização das filhas participantes.

Tabela 12. Indicadores relativos ao processo de pensamento obtidos nos psicogramas das filhas.

Tabela 13. Avaliação dos indicadores relativos ao processo de pensamento obtidos nos psicogramas das filhas.

Tabela 14. Indicadores relativos ao teste do real obtidos nos psicogramas das filhas.

Tabela 15. Avaliação dos indicadores relativos ao teste do real obtidos nos psicogramas das filhas.

Tabela 16. Indicadores relativos à vivência afetiva e ao controle de impulsos obtidos nos psicogramas das filhas

Tabela 17. Avaliação dos indicadores relativos à vivência afetiva e ao controle de impulsos obtidos nos psicogramas das filhas. 
Tabela 18. Indicadores relativos à natureza dos relacionamentos obtidos nos psicogramas das filhas.

Tabela 19. Avaliação dos indicadores relativos à natureza dos relacionamentos obtidos nos psicogramas das filhas

Tabela 20. Resumo da análise realizada a partir dos dados apresentados pelas filhas no Rorschach

Tabela 21. Síntese da análise simbólica no que se refere à construção da identidade e elementos de introjeção

Tabela 22. Síntese da análise simbólica no que se refere ao modo como o indivíduo se relaciona a partir das repostas das filhas.

Tabela 23. Choque às pranchas do Rorschach das filhas participantes.

Tabela 24. Síntese dos dados obtidos no Procedimento de Desenho de Família com Histórias (DF-E) a partir das categorias estabelecidas.

Tabela 25. Síntese da análise psicodinâmica das filhas a partir dos instrumentos utilizados 177

Tabela 26. Resumo dos principais dados obtidos nas entrevistas com as mães 182

Tabela 27. Indicadores relativos à capacidade de realização obtidos nos psicogramas das mães.

Tabela 28. Avaliação da capacidade de realização das mães

Tabela 29. Indicadores relativos ao processo de pensamento obtidos nos psicogramas das mães

Tabela 30. Avaliação dos indicadores relativos ao processo de pensamento obtidos nos psicogramas das mães

Tabela 31. Indicadores relativos ao teste do real obtidos nos psicogramas das mães

Tabela 32. Avaliação dos indicadores relativos ao teste do real obtidos nos psicogramas das mães.

Tabela 33. Indicadores relativos à vivência afetiva e ao controle de impulsos obtidos nos psicogramas das mães

Tabela 34. Avaliação dos indicadores relativos à vivência afetiva e ao controle de impulsos obtidos nos psicogramas das mães.

Tabela 35. Indicadores relativos à natureza dos relacionamentos obtidos nos psicogramas das mãe 
Tabela 36. Avaliação dos indicadores relativos à natureza dos relacionamentos obtidos nos psicogramas das mães

Tabela 37. Resumo da análise realizada a partir dos dados apresentados pelas mães no Teste de Rorschach.....

Tabela 38. Síntese da análise simbólica das mães no que se refere à construção da identidade e elementos de introjeção

Tabela 39. Síntese da análise simbólica das mães no que se refere ao modo como o indivíduo se relaciona.

Tabela 40. Choque às pranchas do Rorschach das mães participantes. 204

Tabela 41. Síntese dos dados obtidos no Procedimento de Desenho de Família com Histórias (DF-E) a partir das categorias estabelecidas

Tabela 42. Síntese da análise psicodinâmica das mães a partir dos instrumentos utilizados 212

Tabela 43. Resumo dos principais dados obtidos nas entrevistas com os pais

Tabela 44. Indicadores relativos à capacidade de realização obtidos nos psicogramas dos pais.

Tabela 45. Avaliação da capacidade de realização dos pais.

Tabela 46. Indicadores relativos ao processo de pensamento obtidos nos psicogramas dos pais.

Tabela 47. Avaliação dos indicadores relativos ao processo de pensamento obtidos nos psicogramas dos pais.

Tabela 48. Indicadores relativos ao teste do real obtidos nos psicogramas dos pais 227

Tabela 49. Avaliação dos indicadores relativos ao teste do real obtidos nos psicogramas dos pais.

Tabela 50. Indicadores relativos à vivência afetiva e ao controle de impulsos obtidos nos psicogramas dos pais.

Tabela 51. Avaliação dos indicadores relativos à vivência afetiva e ao controle de impulsos obtidos nos psicogramas dos pais.

Tabela 52. Indicadores relativos à natureza dos relacionamentos obtidos nos psicogramas dos pais.

Tabela 53. Avaliação dos indicadores relativos à natureza dos relacionamentos obtidos nos psicogramas dos pais 
Tabela 54. Resumo da análise realizada a partir dos dados apresentados pelos pais no teste de Rorschach.

Tabela 55. Síntese da análise simbólica das respostas dos pais no que se refere à construção da identidade e elementos de introjeção.

Tabela 56. Síntese da análise simbólica das respostas dos pais no que se refere ao modo como o indivíduo se relaciona.

Tabela 57. Choque às pranchas do Rorschach dos pais 245

Tabela 58. Síntese dos dados obtidos da aplicação do Procedimento de Desenhos de Família com Estórias (DF-E) nos pais, a partir das categorias estabelecidas. 247

Tabela 59. Síntese da análise psicodinâmica dos pais a partir dos instrumentos utilizados...254 


\section{SUMÁRIO}

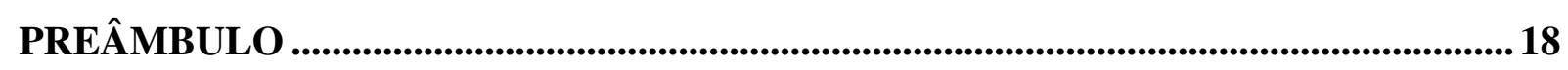

1 INTRODUÇÃO .................................................................................................................... 20

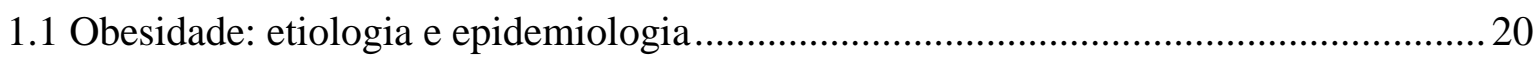

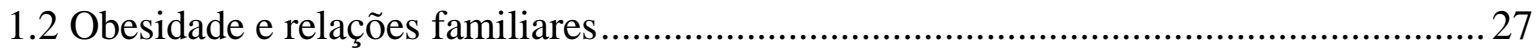

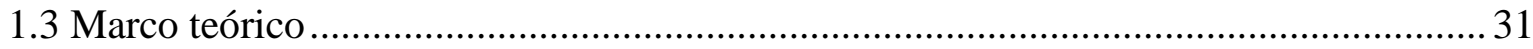

1.3.1 Contribuições da psicanálise para a compreensão das relações familiares ............ 31

1.3.2 As estruturas de personalidade e as organizações limítrofes ..................................... 34

1.3.3 A teoria winnicottiana do amadurecimento emocional ........................................... 42

1.4 Avaliação psicológica e os métodos projetivos ......................................................... 47

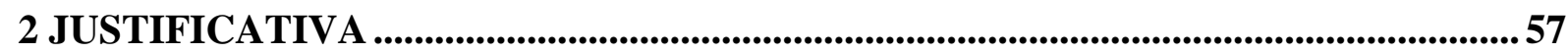

3 OBJETIVOS ......................................................................................................................................... 57

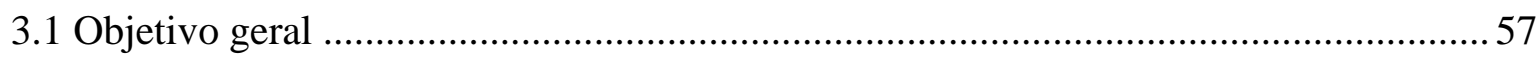

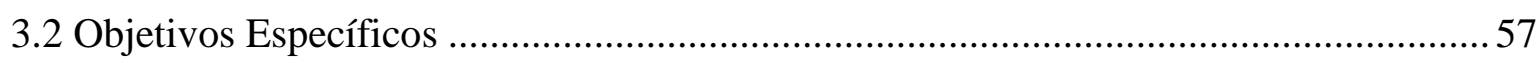

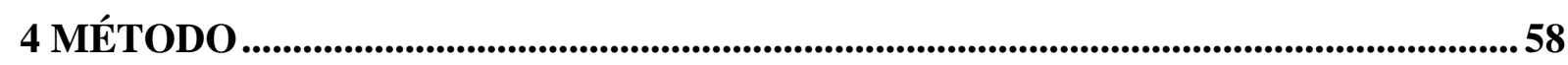

4.1 Referencial Teórico-Metodológico........................................................................ 58

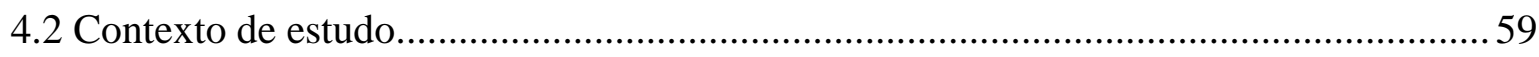

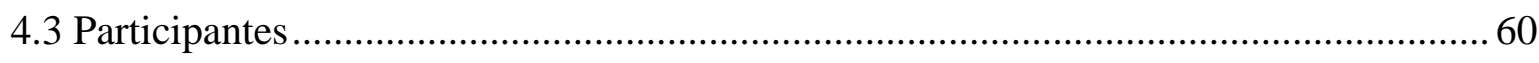

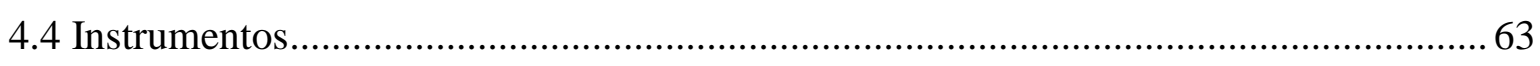

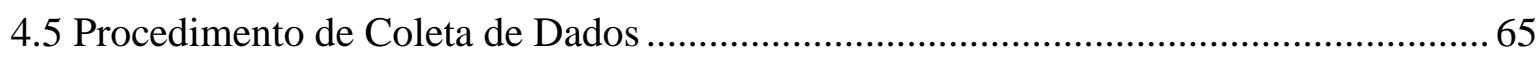

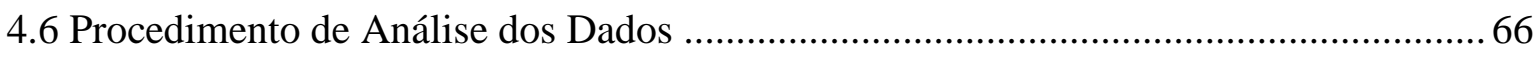

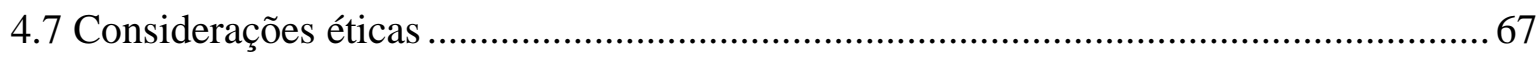

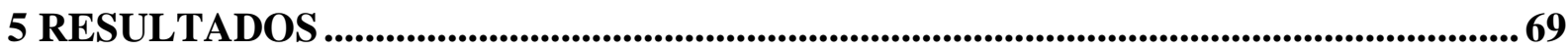

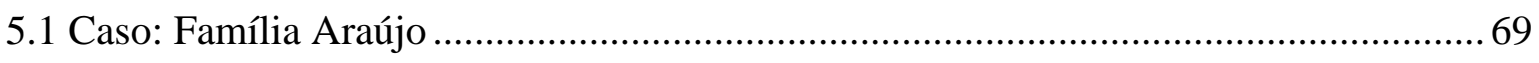

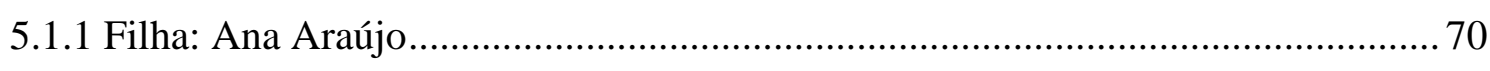

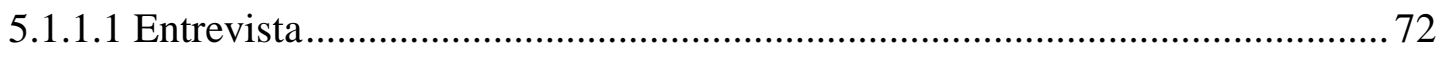

5.1.1.2 Análise qualitativa do Q-EDD ................................................................ 79

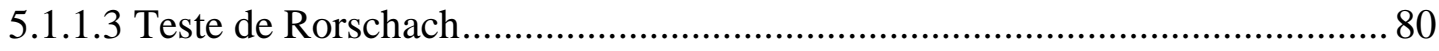


5.1.1.4 Procedimento de Desenhos de Família com Estórias..................................... 88

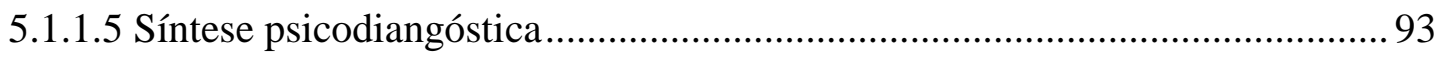

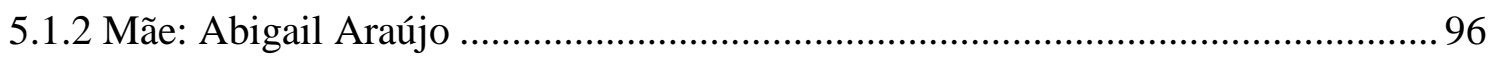

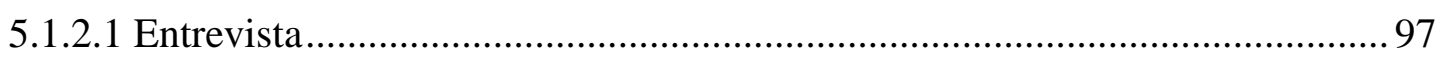

5.1.2.2 Análise qualitativa do Q-EDD ............................................................... 104

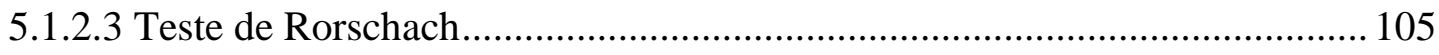

5.1.2.4 Procedimento de Desenhos Família com Estórias ....................................... 112

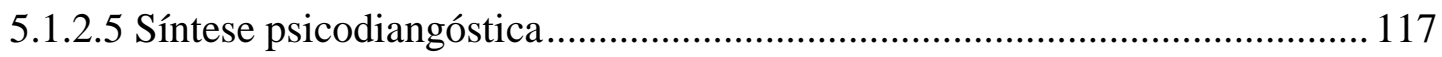

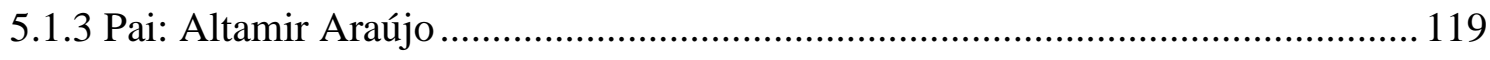

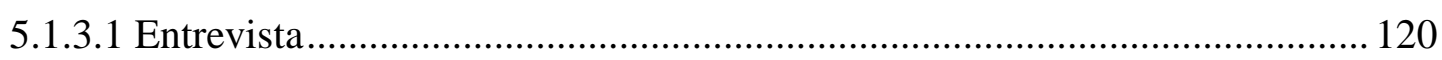

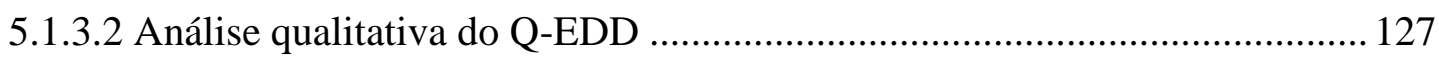

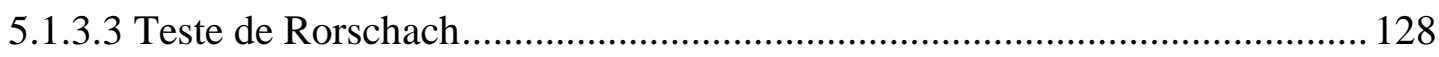

5.1.3.4 Procedimento de Desenhos de Família com Estórias.................................... 137

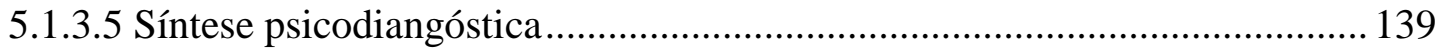

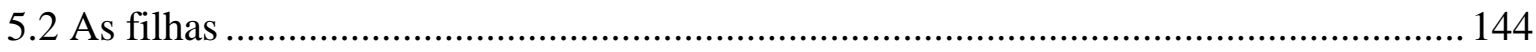

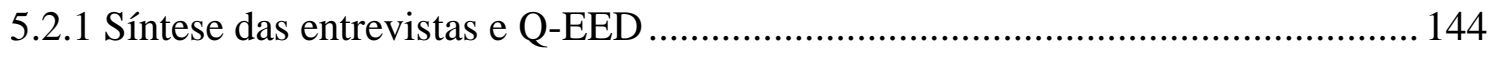

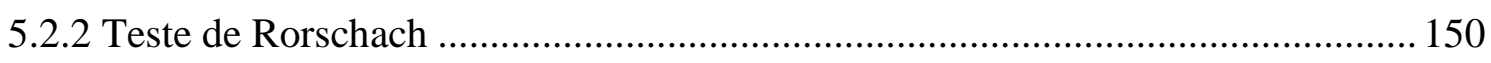

5.2.3 Procedimento de Desenhos de Família com Estórias ......................................... 170

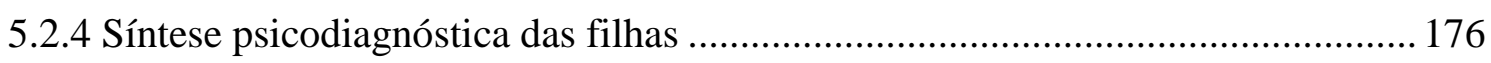

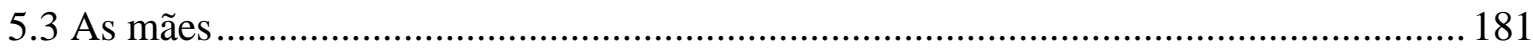

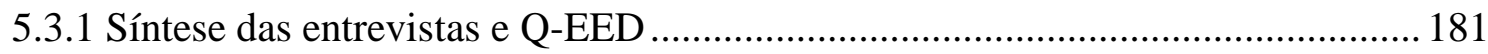

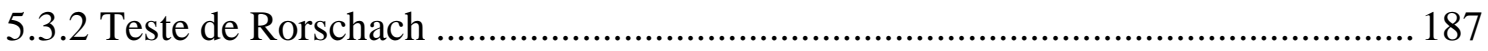

5.3.3 Procedimento de Desenhos de Família com Estórias ........................................205

5.3.4 Síntese psicodiagnóstica das mães ............................................................... 211

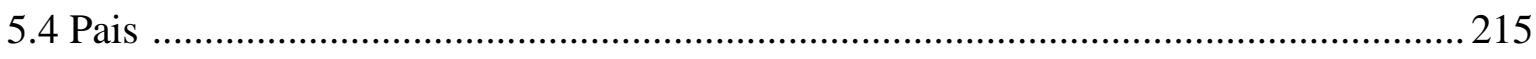

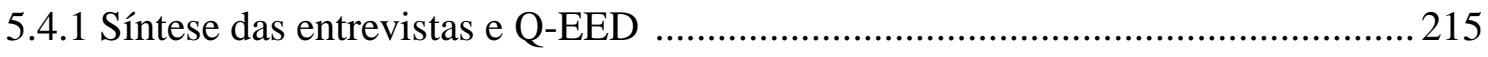

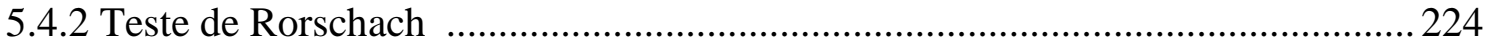

5.4.3 Procedimento de Desenhos de Família com Estórias .........................................246

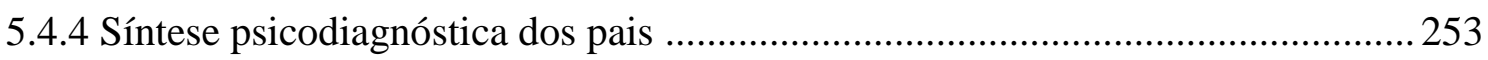

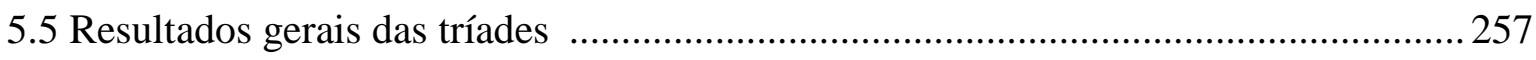

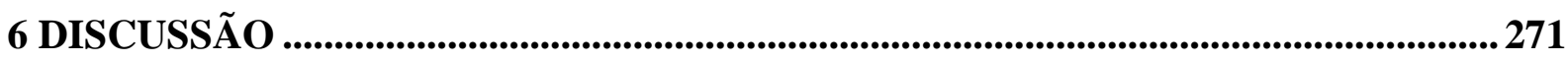

6.1 Psicodinamismos das filhas e suas relações com a obesidade......................................2 271

6.2 Psicodinamismos das mães e suas relações com a obesidade ....................................2.282 
6.3 Psicodinamismos dos pais e suas relações com a obesidade 288

6.4 Psicodinâmica familiar e caracaterísticas de personalidade e características de personalidade de pais, mães e filhas

\section{APÊNDICES}

APÊNDICE A - Formulário de dados sociodemográfios 318

APÊNDICE B - Roteiro de entrevista semiestruturada (Filha) 319

APÊNDICE C - Roteiro de entrevista semiestruturada (Pai).

APÊNDICE D - Roteiro de entrevista semiestruturada (Mãe)

APÊNDICE E - Termo de Consentimento Livre e Esclarecido (Filhas com idade superior a 18 anos)

APÊNDICE F - Termo de Consentimento Livre e Esclarecido (Pais) APÊNDICE G - Termo de Consentimento Livre e Esclarecido (Pais de filhas com idade inferior a 18 anos)

APÊNDICE H - Termo de Assentimento Livre e Esclarecido (Filhas com idade inferior a 18 anos). 328

APÊNDICE I - Psicograma das filhas 330

APÊNDICE J - Psicograma dos pai 335

APÊNDICE K - Psicograma das mães. 340

\section{ANEXOS}

ANEXO 1 -Critério de Classificação Socioeconômica Brasil 346

ANEXO 2 - Questionnaire for Eating Disorder Diagnosis 347

ANEXO 3 - Protocolo para avaliação simólica do Teste de Rorschach

ANEXO 4 - Protocolo para avaliação das funções egóicas no Teste de Rorschach 353

ANEXO 5 - Aprovação do Comitê de Ética em Pesquisa da FFCLRP-USP 354 ANEXO 6 - Termo de Autorização 


\section{PREÂMBULO}

O presente projeto está inserido em uma pesquisa mais ampla, intitulada "Transtornos alimentares, Obesidade e família: uma perspectiva transcultural”, que é produto da parceria entre o Programa de Pós-graduação em Psicologia da Faculdade de Filosofia, Ciências e Letras de Ribeirão Preto da Universidade de São Paulo (FFCLRP-USP) e o Centre d'Études en Psychopathologie et Psychanalyse, da Université Paris-Diderot, da França.

O objetivo central desse projeto transcultural é investigar, por meio de uma avaliação projetiva, o funcionamento familiar e as características de personalidade de jovens que apresentam transtornos alimentares ou Obesidade e de seus pais e mães, em comparação com jovens que não apresentam diagnósticos psiquiátricos e que tenham peso normal e seus respectivos genitores, no Brasil e na França. No total, o projeto contará com a participação de 60 famílias, 30 brasileiras e 30 francesas. Em cada país, participarão 10 famílias com filhas que receberam diagnóstico de Transtorno Alimentar (TA); 10 famílias com filhas com Obesidade e 10 famílias que irão compor o grupo de comparação. O recorte realizado para este projeto de doutorado envolve o estudo das 10 famílias brasileiras nas quais a filha apresenta Obesidade. A comparação com as outras famílias participantes do estudo, tanto brasileiras como francesas, será realizada em etapa posterior à execução desse projeto, por toda a equipe de pesquisa.

O projeto maior tem como pesquisadoras responsáveis a Profa. Dra. Claire Squires (França) e a Profa. Dra. Valeria Barbieri (Brasil). No Brasil, conta também com as contribuições do Prof. Dr. Manoel Antônio dos Santos, das Dras. Érika Arantes de Olivera e Irma Helena Ferreira Benate Bomfim e da Doutora Élide Dezoti Valdanha que realizou a coleta de dados com o grupo brasileiro de filhas que receberam diagnóstico de TAs.

Para ingressar nesse projeto de pesquisa, tenho como alicerce minha trajetória como pesquisadora no campo dos Transtornos Alimentares (TAs) desde a minha graduação, quando ingressei como estagiária no Grupo de Assistência a Transtornos Alimentares (GRATA). Logo em seguida, ainda no GRATA, realizei a coleta de dados para minha Dissertação de Mestrado, intitulada "Relação pai-filha no contexto dos transtornos alimentares: uma perspectiva winnicottiana” e atuei como psicóloga voluntária nessa instituição. Ao longo da pesquisa de mestrado, tive a experiência de estudar relações familiares e suas repercussões no comportamento alimentar das filhas, além de perceber, por meio da teoria winnicottiana e da utilização do Procedimento de Desenhos de Família com Estórias (DF-E), como a psicanálise e a avaliação psicológica podem contribuir para a compreensão desse tema. 
A realização do mestrado despertou meu interesse em ampliar a investigação na área do comportamento alimentar, desejando compreender como a mãe se insere de fato nessa dinâmica, já que ela surgia frequentemente nos conteúdos projetados pelo pai e pela filha no material de avaliação. Além disso, percebi a necessidade de compreender também os relacionamentos nas famílias cujos filhos são obesos, pois TAs e Obesidade estão extremamente próximos; todavia, essa proximidade não pode encobrir as divergências importantes entre esses quadros, que precisam ser consideradas na estruturação de tratamentos especializados.

Meu trabalho como Professora Substituta no Departamento de Psicologia da Universidade Federal do Triângulo Mineiro (UFTM), principalmente nas disciplinas de Psicopatologia Geral e Psicologia da Saúde, ampliou minha percepção sobre os impactos da Obesidade em diferentes setores de assistência à saúde, bem como sobre a demanda por estudos que investiguem a relação entre psicopatologias e o comportamento alimentar. Atuo também como psicóloga do Departamento de Ortopedia e Traumatologia do Hospital das Clínicas da Faculdade de Medicina de Ribeirão Preto (HCFMRP-USP), que recebe um número grande de pacientes obesos devido às comorbidades como osteoartrose. Por vezes, o tratamento desses pacientes é prejudicado pelas outras patologias associadas ao excesso de peso, como as cardiovasculares. Além disso, após procedimentos cirúrgicos, pelas próprias limitações corporais ocasionadas pela Obesidade, muitos têm um processo de reabilitação mais demorado e se mostram mais dependentes em relação à equipe de enfermagem. Esses dados intensificaram meu interesse em investigar estratégias que possam colaborar com a melhor assistência a esse perfil de paciente.

Foi essa experiência que me conduziu a ingressar na equipe do projeto de pesquisa 'Transtornos Alimentares, Obesidade e Família: uma perspectiva transcultural' e assumir a responsabilidade por uma parte fundamental dessa investigação. Dessa maneira, mergulhei nesse universo e estou construindo minha parte individual nesse projeto, por meio de revisão bibliográfica, definição de metodologia, coleta e análise dos resultados encontrados, discussão, considerações finais, referências, anexos e apêndices. 


\section{INTRODUÇÃO}

No intuito de abordar as diferentes faces da temática na qual se debruça o presente estudo, a saber, a obesidade, esta Introdução foi dividida em quatro tópicos. No primeiro, foi exposto um breve panorama do estado de arte das investigações científicas relativas à obesidade na atualidade, no Brasil e no mundo, com destaque para aspectos epidemiológicos e etiológicos dessa condição. Em seguida, no segundo tópico, buscou-se mapear a literatura que entrelaça dados sobre características familiares e a obesidade. No terceiro tópico, foi introduzido o referencial teórico que fundamenta as análises realizadas, a psicanálise,

primeiramente discorrendo sobre as contribuições psicanalíticas para a compreensão das relações familiares, depois sobre as características e estruturas de personalidade a partir da teoria de Bergeret (1988) e, posteriormente, as formulações winnicottianas sobre o desenvolvimento humano. Por último, no quarto tópico, foi realizada uma breve apresentação histórica sobre a avaliação psicológica e os métodos projetivos, com foco nas técnicas que compõem a estratégia metodológica adotada nesse estudo.

\section{Obesidade: epidemiologia e etiologia}

Durante séculos, a obesidade foi vista como indicador de riqueza, beleza e saúde. Entretanto, atualmente ela é considerada uma doença crônica, caracterizada pelo excesso de tecido adiposo no organismo (Bohnert et al., 2020). Existem dois subtipos de obesidade: endógena, relacionada a alterações no metabolismo do indivíduo devido à causas orgânicas; e exógena ou nutricional, causada por fatores relacionados ao estilo de vida, como o consumo de grande quantidade de calorias superior ao gasto energético (Silva \& Dionísio, 2019).

No que se refere à etiologia da obesidade, são vários os fatores que, combinados, colaboram para gerar o acúmulo de peso, como características genéticas; dinâmica das relações familiares; fatores socioculturais e midiáticos que, por um lado, perpetuam o sedentarismo e a ingestão de alimentos altamente calóricos e, por outro, associam a beleza à magreza através da valorização de corpos femininos com medidas antropométricas, muitas vezes, inalcançáveis para a maioria da população (Francischi et al., 2000; Kalra et al., 2012; Dantas \& Silva, 2019; Bohnert et al., 2020).

Ainda não se sabe ao certo o grau de influência de cada um desses fatores para o desenvolvimento e a manutenção da obesidade. Em relação ao fator genético, os mecanismos pelos quais ele opera são ainda mais desconhecidos. Francischi et al. (2000) descreveram que 
a genética atuaria no balanço entre o consumo e o gasto energético (Taxa Metabólica Basal do organismo - TMB), no controle do apetite e no comportamento alimentar. Segundo Latzer e Stein (2013), essa influência genética aumenta em torno de 50\% o risco de sobrepeso e obesidade infantil; as doenças genéticas ou endócrinas são responsáveis por menos de 10\% dos casos e os distúrbios hipotalâmicos ou obesidade induzida pelo uso de medicamentos são ainda mais raros.

Ao considerar que não aconteceram grandes modificações no mapa genético do ser humano nas últimas três décadas, Latzer e Stein (2013) defendem que os fatores ambientais, socioculturais e psicológicos são os que mais explicam o aumento do sobrepeso e da obesidade nos últimos anos. De acordo com Ferreira et al. (2019), o alto consumo de fastfood, a não realização de atividade física com frequência, assistir televisão por longos períodos de tempo e se alimentar enquanto realiza essa prática são alguns hábitos comuns na atualidade que podem intensificar o ganho de peso.

A obesidade é alvo de preocupação entre os profissionais da saúde, principalmente pelas comorbidades que lhe são associadas, como doenças cardiovasculares, diabetes mellitus tipo 2, osteoartrite e, inclusive, aumento do risco de desenvolvimento de alguns tipos de câncer, dentre outras patologias que reduzem a qualidade de vida do indivíduo e aumentam a sobrecarga dos sistemas de saúde (Pulgarón, 2013; Costa et al., 2018; Farias et. al. 2020).

Os altos índices de pessoas que apresentam excesso de peso têm se tornado alarmantes, a ponto de hoje a doença ser vista como uma epidemia e um dos maiores problemas de saúde pública, não só nos países desenvolvidos, como acontecia antes, mas também naqueles em desenvolvimento, como o Brasil (Kalra et al, 2012; Farias et al., 2020). Haslam e James (2005) informam que em todo o mundo há mais de 1 bilhão e 100 milhões de adultos acima do peso considerado normal. Farrell (2004) declara que a taxa de obesidade no mundo aumentou em torno de 250\% entre os anos de 1980 e 1998.

Segundo Ferreira et al. (2019), desde 1975, o Brasil vivencia o processo de transição nutricional, assim como outros países em emergência, que se refere à diminuição das taxas de desnutrição e o aumento do excesso de peso. Ferreira et al., a partir de um estudo dos dados da Pesquisa Nacional de Saúde (PNS), divulgada pelo Instituto Brasileiro de Geografia e Estatística (IBGE) no ano de 2013, destacaram que mais da metade dos brasileiros participantes, acima de 18 anos de idade, apresentava excesso de peso (56,5\% dos homens e $58,9 \%$ das mulheres).

Recentemente, o IBGE divulgou resultados ainda mais alarmantes sobre o aumento da obesidade no país (IBGE, 2019a). De acordo com a PNS, realizada por esse órgão no ano de 
2019, aproximadamente $25,9 \%$ dos brasileiros a partir dos 18 anos de idade estavam obesos e 60,3\% apresentavam sobrepeso. Nos últimos seis anos (entre 2013 e 2019), os resultados revelaram um aumento de $12,2 \%$ para $26,8 \%$ do diagnóstico de obesidade na população do país com mais de 20 anos de idade.

Os dados avaliados por Ferreira et al. (2019) da PNS de 2013 mostraram que o grupo com maior incidência da obesidade é composto pelas mulheres entre 50 e 59 anos. Entretanto, no caso delas, independente da faixa etária, foi encontrado que quanto menor a escolaridade, maior é a chance de ser obesa. $O$ fator cor da pele também foi identificado como uma variável que interfere na obesidade feminina, sendo maior sua incidência entre as mulheres negras. Nos dados dos homens, a cor da pele não se mostrou como uma variável estatisticamente significativa. No que se refere à escolaridade, os resultados deles foram opostos aos das mulheres: o aumento da incidência da obesidade apareceu associada ao maior tempo de estudo.

Ferreira et al. (2019) também revelaram que a obesidade aumenta sua incidência proporcionalmente em proporção direta com a idade, mas diminui a partir dos 60 anos. Sobre a redução da taxas de obesidade entre os idosos, eles consideraram a necessidade de parâmetros de avaliação específicos para essa faixa etária, visto que as significativas mudanças corporais provocadas pelo envelhecimento, como a acentuada perda de massa muscular, enviesam os dados.

As informações epidemiológicas sobre o tema evidenciam que o crescimento acentuado da incidência da obesidade atinge todas as faixas etárias, grupos sociais e gêneros, porém em alguns segmentos da população o assunto é ainda mais preocupante (Costa et al., 2018). No que se refere ao gênero, como vimos, os dados da PNS de 2019 revelaram que as mulheres continuam sendo as mais atingidas. Na população feminina de 20 anos ou mais, a incidência da obesidade, entre os anos de 2013 e 2019, passou de 14,5\% para 30,2\%, enquanto a porcentagem de homens obesos da mesma idade, apesar de também ter aumentado, manteve-se inferior à das mulheres: subiu de 9,6\% para 22,8\% (IBGE, 2019a).

Os estudos atribuem a maior prevalência da obesidade no sexo feminino ao fato das mulheres serem mais atingidas pelas pressões sociais relacionadas aos padrões de beleza e estético, além de características biológicas do corpo da mulher, como aspectos hormonais do ciclo menstrual, que podem colaborar com a aceleração do ganho de peso (Scotton et al., 2019. Ferreira et al., 2019).

Para Costa et al. (2018), nas mulheres jovens adultas, a obesidade demanda atenção diferenciada, uma vez que elas são ainda mais atingidas pelas idealizações sociais referentes à 
imagem corporal, além das maiores chances de se manterem obesas durante toda a vida. A obesidade feminina nessa faixa etária pode provocar, por exemplo, prejuízos na vida reprodutiva, como dificuldade para engravidar ou o maior risco de complicações em possíveis gestações; restrições logo no início do exercício profissional por conta das limitações físicas provocadas pelo excesso peso, além de outras repercussões da obesidade que afetam com mais intensidade a saúde da mulher (Martini et al., 2020).

Em ambos os sexos, o excesso de peso entre adultos jovens é influenciado tanto pelos efeitos da transição da infância para a adolescência, quanto da adolescência para a idade adulta, em decorrência das significativas transformações físicas e psicológicas que caracterizam esses períodos (Reed et al., 2017). Nesse sentido, Costa et al. (2018) consideraram que os programas de tratamento necessitam oferecer lugar de destaque a essa parcela da população, uma vez que quanto mais precoce for a intervenção, maiores as probabilidades de alcançar boa eficácia, além do fato de que os resultados repercutem nos grupos etários seguintes.

Nesse contexto, na adolescência, as taxas de obesidade também são altas (Martini et al., 2020). No Brasil, a Pesquisa Nacional de Saúde do Escolar, realizada no ano de 2015, constatou que, na população de 13 a 17 anos de idade, 23,7\% foram classificados com sobrepeso e 7,8\% com obesidade. Tamayo et al. (2020), ao estudarem adolescentes espanhóis obesos, identificaram que o histórico de obesidade na família e de distúrbios lipídicos nos pais foram os principais fatores de risco para o excesso de peso encontrados nos seus participantes. As comorbidades mais identificadas nos adolescentes foram problemas ortopédicos, o que estaria relacionado ao fato da obesidade prejudicar a adaptação às mudanças na estrutura óssea que ocorrem nessa fase.

D'avila et al. (2019) verificaram que adolescentes com excesso de peso apresentam prejuízos acentuados na qualidade de vida relacionada à saúde, que no caso dos obesos são ainda mais significativos. Os participantes do seu estudo evidenciaram perdas, principalmente nos domínios físico e escolar. D’avila et al. consideraram que o uso prolongado da internet, a maior tendência ao isolamento social e a experiência de condições emocionais desfavoráveis são alguns dos fatores observados nos adolescentes obesos que contribuem para a redução da qualidade de vida. Sobre o desempenho acadêmico, eles demonstraram piores pontuações e maior tendência à evasão escolar.

Na infância, apesar da incidência da obesidade ser menor, esse é o grupo etário que desperta maior preocupação nas autoridades de saúde, por conta dos prejuízos do excesso de peso em diferentes âmbitos do desenvolvimento infantil, além da maior probabilidade da 
obesidade se manter na idade adulta (Bohnert et al., 2020; Noh et al., 2020). Mendes et al. (2019) acrescentaram que o excesso de peso está associado a uma maior taxa de mortalidade infantil em função das várias complicações físicas e emocionais que essa condição pode desencadear.

Nesse contexto, destaca-se a crescente literatura que menciona o cenário catastrófico provocado pela obesidade infantil e suas repercussões. São vários os estudos que relatam o crescimento exponencial do número de crianças com sobrepeso e obesas (Farias et al. 2020; Bohnert et al., 2020; Mendes et al., 2019). Nesse ritmo, em 2025, a Organização Mundial de Saúde estima que o número de crianças obesas no mundo pode chegar a 75 milhões. Para Latzer e Stein (2013), a obesidade infantil será o problema de saúde mais importante do mundo.

No Brasil, os dados do IBGE (2019b) revelaram que uma a cada três crianças, entre cinco e nove anos de idade, está acima do peso esperado para o seu grupo de referência. O Sistema de Vigilância Alimentar e Nutricional (SISVAN), que é uma das referências da Política Nacional de Alimentação e Nutrição (PNAN), do Sistema Único de Saúde (SUS), informou no estudo realizado em 2019 que 16,33\% das crianças brasileiras, na faixa dos cinco a dez anos, estão apresentam sobrepeso; dentre elas 9,38\% cumprem critérios para o diagnóstico de obesidade e 5,22\% o de obesidade grave.

Em meio à grande extensão do país, Farias et al. (2020) ressaltaram a importância do desenvolvimento de estudos epidemiológicos e de políticas públicas que considerem as diferenças regionais para o enfretamento da obesidade. A pesquisa de Farias et al. revelou alta prevalência da obesidade infantil em crianças da região norte do país, em todas as faixas etárias e classes sociais, porém mostrou que são raras as políticas públicas que se atentam para essa região do Brasil.

A Organização Mundial de Saúde recomenda a utilização do Índice de Massa Corporal (IMC) como critério para o diagnóstico da obesidade do adulto. O IMC pode ser obtido por meio da divisão do peso do indivíduo (em quilogramas $-\mathrm{kg}$ ) por sua altura (em metros $-\mathrm{m}$ ) elevada ao quadrado. A faixa de normalidade do IMC para a população adulta vai de 18,5 a $24,9 \mathrm{~kg} / \mathrm{m}^{2}$. Pessoas que possuem IMC acima dessa faixa podem ter sobrepeso (entre $25 \mathrm{e}$ $29,9 \mathrm{~kg} / \mathrm{m}^{2}$ ); Obesidade grau I (entre 30 e $34,9 \mathrm{~kg} / \mathrm{m}^{2}$ ); Obesidade grau II (entre 35 e 39,9 $\mathrm{kg} / \mathrm{m}^{2}$ ) ou Obesidade grau III (acima de $40 \mathrm{~kg} / \mathrm{m}^{2}$ ).

Já para a população infantil, não existe um padrão mundial de diagnóstico da obesidade. A transposição dos valores utilizados em adultos nem sempre fundamenta uma boa avaliação (Latzer \& Stein, 2013). Dessa forma, o método atual mais utilizado para avaliação 
da obesidade infantil se baseia na análise de percentis proposta pelo Centro Americano para Controle de Doenças (Center for Disease Control - CDC). O CDC considera que indivíduos entre 2 e 19 anos podem ser considerados obesos quando possuírem IMC localizado acima do percentil 97 para sua idade e sexo.

Nos casos em que a obesidade está associada ao sofrimento psicológico, Sousa (2008) defende que, além do IMC, é necessário investigar a percepção do indivíduo acerca do seu peso e sua imagem corporal, pois as autorrepresentações podem influenciar no desenvolvimento de maior ou menor padecimento. Sousa prossegue afirmando que, nesse aspecto, o fator gênero também aparece como um mediador importante, uma vez que, em comparação aos homens, as mulheres tendem a se considerar mais 'gordas' do que de fato são (Scotton et al., 2019).

Além dos prejuízos à saúde física, a obesidade poder acarretar danos à saúde mental, embora o excesso de peso não implique necessariamente na vivência de conflitos psicológicos; é por isso que ela não é considerada como uma psicopatologia por si só. Apesar de não haver uma relação direta, a literatura científica evidencia que há sofrimentos emocionais presentes em maior frequência em indivíduos obesos, como dificuldades relativas à imagem corporal, baixa autoestima, redução do contato social, depressão e ansiedade (Scotton et al., 2019; Rocha \& Costa, 2012). A obesidade pode estar associada também ao desenvolvimento de transtornos mentais, dentre eles, os Transtornos Alimentares (TAs), o Transtorno de Déficit de Atenção-Hiperatividade (TDAH) e problemas de sono (Kalra et al., 2012).

Ainda sobre as psicopatologias associadas à obesidade, Sansone e Sansone (2013) indicam a alta comorbidade entre a obesidade e o Transtorno da Personalidade Borderline. De acordo com eles, os transtornos da personalidade começam a se consolidar na infância, o que faz ser provável que a patologia da personalidade seja anterior à obesidade na maioria dos casos. Entretanto, essa conclusão é arriscada, uma vez que o excesso de peso também pode acarretar uma série de consequências psicológicas no indivíduo (Segal et al. 2002).

$\mathrm{Na}$ literatura, existem relatos tanto de que a obesidade se encontra na origem de vários sofrimentos psicológicos, quanto hipóteses de que são estes últimos que favorecem a obesidade (Kalra et al., 2012; Pulgarón, 2013). A escassez de estudos prospectivos que se dedicam a esse tema não permite chegar a uma visão mais nítida desses interrelacionamentos. Sabe-se que, ao invés de estabelecer uma relação de causa e efeito entre o excesso de peso e suas comorbidades físicas e emocionais, é necessário considerar uma teia complexa de relações entre elas, que torna difícil identificar o quê foi o disparador do quê. 
Como dito anteriormente, são vários os fatores associados ao desenvolvimento e manutenção da obesidade, o que aumenta a complexidade do tema e exige atenção multiprofissional (Scotton et al., 2019).

Em um estudo transversal, realizado com 184 pacientes que procuraram por tratamento para sobrepeso e obesidade, Scotton et al. (2019) encontraram que, em diferentes proporções, sintomas de origem psicológica estão presentes na população estudada. Seus resultados apontaram para o fato de que as sintomatologias psiquiátricas aumentam sua prevalência em paralelo ao aumento do IMC, da mesma forma que se manifestam com mais frequência nas mulheres (Silva \& Dionísio, 2019). Elas apresentaram índices mais elevados de sintomas depressivos, sinais de ansiedade e desesperança, além de uma maior tendência a superestimarem o tamanho dos seus corpos. É necessário considerar que 80\% da amostra era composta por mulheres, portanto, apesar do maior sofrimento psíquico, parece haver uma maior tendência feminina a solicitar por apoio. Os homens demonstraram procurar suporte em situações de maior gravidade, já que a média do IMC deles foi superior à delas $\left(38, \mathrm{~kg} / \mathrm{m}^{2} \mathrm{e}\right.$ $32,5 \mathrm{~kg} / \mathrm{m}^{2}$, respectivamente).

Os conflitos psicológicos suscitados pela obesidade não podem ser considerados apenas como consequência da patologia por si só, mas também pelas representações sociais atribuídas ao assunto. $\mathrm{Na}$ sociedade ocidental, por exemplo, observa-se que o aumento da preocupação com a aparência, juntamente com a valorização do corpo magro, acarreta como consequência o preconceito e a discriminação contra pessoas obesas (Sousa, 2008). Diante desse cenário, Segal et al. (2002) lembram que indivíduos obesos terminam por frequentar a escola por menos tempo, têm uma probabilidade mais baixa de serem aceitos em universidades e trabalhos mais competitivos, recebem salários mais baixos e têm menos relações amorosas estáveis. As crianças obesas, frequentemente, são estigmatizadas como preguiçosas, egoístas e menos saudáveis, julgamentos que se baseiam em crenças de que a obesidade é algo possível de ser controlado e que seria uma dificuldade exclusiva do indivíduo (Mendes et al., 2019; Sagui-Henson et al., 2019).

Atualmente, a pandemia causada pela COVID-19 intensificou as preocupações relacionadas ao tema, já que foi observado um número de vítimas da doença superior entre os obesos, principalmente por conta das comorbidades associadas ao excesso de peso, que são fatores de risco para o agravamento da doença, como a diabetes. Embora ainda não se tenha uma dimensão das consequências da pandemia para a saúde da população, já há relatos sobre a intensificação do ganho de peso nos últimos meses, principalmente entre as crianças e adolescentes, em decorrência do fechamento das escolas e do isolamento social, além da piora 
na qualidade do sono e o aumento do estresse, fatores que também interferem na qualidade alimentar (Nogueira-de-Almeida et al., 2020).

No âmbito das políticas públicas, Martini et al. (2020) citam que o governo brasileiro tem investido em estratégias que visam reduzir a prevalência da obesidade, sobretudo nas crianças, como o incentivo ao aleitamento materno, oferta de alimentação balanceada nas escolas e controle de propagandas de alimentos voltadas para os mais jovens. Entretanto, os dados recentes sobre o acentuado aumento da obesidade no Brasil denunciam que as medidas adotadas não estão se mostrando eficazes (IBGE, 2019, Ferreira et al., 2019).

Dantas e Silva (2019) destacam que, quando se realiza intervenções de caráter multidisciplinar, em nível individual e familiar, além do coletivo, os efeitos nocivos do ambiente obesogênico da atualidade, que estimula o elevado consumo de alimentos calóricos e pouco nutritivos, podem ser minimizados e colaborar para a obtenção de melhores resultados no combate à obesidade. Apesar dessas evidências, Younes et al. (2017) destacam a escassez de tratamentos para a obesidade que ofereçam suporte multiprofissional no contexto brasileiro, assim como a falta de atenção a essa patologia na assistência básica, o que poderia colaborar para o desenvolvimento de estratégias preventivas e de tratamento em estágios iniciais, quando os prejuízos experienciados são menores (Ferreira et al., 2019).

No que se refere ao âmbito científico, embora se tenha conhecimento sobre a etiologia multifatorial da obesidade, Mishima e Barbieri (2009a) descrevem que as pesquisas sobre o tema têm se concentrado principalmente nos fatores biológicos e socioculturais promotores e mantenedores desse quadro em detrimento dos aspectos psicológicos. Consequentemente, as propostas de tratamento centram-se em estratégias que visam mudanças nos hábitos alimentares, e, com frequência, desconsideram os psicodinamismos do indivíduo com obesidade e todo o sofrimento envolvido (Camargo, 2013; Henriques et al., 2015; Fisberg, 2005).

\subsection{Obesidade e relações familiares}

Dentre os fatores passíveis de colaborar para o surgimento das novas patologias e a maior presença de outras que não eram observadas com tanta frequência, como a obesidade, encontram-se as mudanças no processo de desenvolvimento da personalidade do indivíduo. As origens dessas alterações estão associadas às modificações nas relações familiares (Barbieri, 2013). A família, por sua vez, reflete as transformações sociais que a humanidade vivencia (Mandebaum, 2012). Sobre o assunto, Durham (1983) destaca que a família é fruto 
da criação social e se modifica a partir do modo como o cenário político-econômico se reorganiza.

Recentemente, as famílias brasileiras têm vivido intensas transformações, inclusive no que se refere ao exercício da função paterna e materna. Até por volta da década de 50, o trabalho masculino se constituía como a única fonte de renda das famílias. Desse modo, cabia à mulher o cuidado dos filhos e as tarefas domésticas (Borsa \& Nunes, 2011). Com a inserção da mulher no mercado de trabalho, dentre outras mudanças sociais e econômicas que a sociedade enfrentou após a revolução industrial, tornou-se necessária a redução das diferenças na divisão de trabalho entre homens e mulheres, como a maior presença do pai nos cuidados dos filhos (Hennigen, 2010).

Apesar das mudanças, Staudt e Wagner (2008) revelaram que a inserção paterna no cuidado dos filhos e trabalhos domésticos ainda é muito inferior em relação à participação feminina no mercado de trabalho. Além disso, embora seja possível perceber um maior interesse dos pais (masculinos) em se aproximar dos filhos, eles enfrentam dificuldades em encontrar referenciais para o exercício da paternidade, já que, muitas vezes, tiveram como modelo figuras paternas distantes do ambiente doméstico (Jaber \& Bottoli, 2011).

Da mesma forma que o pai, as mulheres também têm enfrentado dificuldades para incorporar as novas funções exigidas dos papéis masculino e feminino. Perucchi e Beirão (2007) verificaram que mulheres chefes de famílias mononucleares associam o papel do pai à função de exercer autoridade; já a mulher seria representada como a figura que detém, em maior escala, a função de manutenção do vínculo afetivo com os filhos; é nesse quesito que elas sentiam falta da presença paterna. Sobre isso, destaca-se que, na atualidade, ainda é marcante a exigência de total devoção da mãe aos filhos, o que, muitas vezes, leva a mulher a anular outros âmbitos da sua vida, como a vivência da própria sexualidade (Leonidas, 2016).

No que se refere às relações familiares de pessoas obesas, elas têm sido descritas tanto como facilitadoras para o desenvolvimento de hábitos alimentares inadequados, como para o amortecimento ou acentuação de conflitos emocionais suscitados pelo excesso de peso, principalmente em crianças e adolescentes. Os pais assumem o papel de modelos de comportamento alimentar para os filhos. Younes et al. (2017), em um estudo que investigou o itinerário terapêutico de pacientes obesos, apontaram para o fato de que a família exerce maior influência no tratamento para a obesidade do que o próprio meio onde esse indivíduo está inserido.

A participação da família como fator etiológico da obesidade ocorre por razões mais evidentes, como a seleção de alimentos e padrões de nutrição dentro do lar que colaboram 
para o aumento do peso, mas também por motivos mais profundos e latentes, como a vivência de angústias no exercício da parentalidade que contribuem para que os pais superalimentem seus filhos (Kalra et al., 2012; Westen et al., 2019). Essas características da família podem influenciar não somente a forma como o filho conduz sua alimentação, mas também a relação dele com o próprio corpo e o modo como vivencia a alimentação, bem como em outros âmbitos de sua vida (Latzer \& Stein, 2013).

Dentre as dificuldades enfrentadas nas famílias de indivíduos obesos, segundo Latzer e Stein (2013), está a pouca percepção dos pais quanto ao excesso de peso do filho. Eles tendem a se preocupar mais com o baixo peso e comportamentos de restrição alimentar, do que com o sobrepeso e o comer compulsivo (Lydecker et al., 2020). Hirschler et al. (2006), em estudo com mães de crianças argentinas, relataram que 90,8\% delas cujos filhos exibiam sobrepeso apresentaram uma percepção distorcida do peso da criança, concebendo-o como normal; dentre as mães cujos filhos tinham peso normal, apenas 36,3\% apresentaram uma percepção distorcida. Esses autores também encontraram que $96 \%$ das mães cujos filhos eram obesos e $84 \%$ daquelas cujos filhos tinham sobrepeso relataram que eles se alimentavam corretamente ou não comiam o suficiente.

Diante desses achados, Hirschler et al. (2006) concluíram que as percepções alteradas das mães e suas crenças equivocadas sobre os hábitos alimentares dos filhos configuram-se como fatores de risco para a obesidade, uma vez que colaboram para que os últimos tenham uma percepção distorcida acerca do próprio corpo. Da mesma forma que as figuras parentais, Martini et al. (2020) encontraram que adolescentes obesas também enfrentam prejuízos na percepção do seu excesso de peso e o pouco reconhecimento dos riscos das comorbidades associadas à obesidade. Para Latzer e Stein (2013), tanto a preocupação exagerada, quanto a despreocupação podem favorecer a manutenção da obesidade, bem como de práticas alimentares pouco saudáveis.

O fato de os próprios pais serem obesos ou adotarem hábitos alimentares inadequados também pode ser um facilitador para o desenvolvimento da obesidade nos filhos (Westen et al., 2020). Essa influência vai além da transmissão de atitudes alimentares irregulares, estando também associada ao modo como se constitui o relacionamento entre pais e filhos (Mendes et al, 2019; Bohnert et al., 2020).

Golan et al. (1998) verificaram que pais e mães obesos são mais rígidos quanto aos hábitos alimentares e críticos diante do ganho de peso da prole. Além disso, tendem a subestimar as dificuldades enfrentadas pelos filhos na tentativa de mudarem hábitos alimentares inadequados. Para Latzer e Stein (2013), isso ocorre porque, em comparação com 
pais que apresentam peso normal, eles se preocupam mais com a possibilidade da criança se tornar obesa no futuro. Em contrapartida, quando a mãe demonstra uma alimentação restrita na tentativa de manter um baixo peso, os filhos apresentam uma forte tendência para terem excesso de peso (Farrell, 2004; Somaraki et al., 2020).

Hughes et al. (2008) verificaram que tanto a rigidez e o autoritarismo dos pais, como o excesso de permissividade aumentam as chances de o filho apresentar sobrepeso e obesidade. Agras e Mascola (2005) relataram que a presença de mães superprotetoras e de pais distantes afetivamente é um padrão familiar observado com frequência nos lares de crianças obesas. A superproteção pode despertar na criança ansiedade de separação dos pais sempre que uma situação de stress se apresenta. Nesses momentos, essas mães culminam na utilização da comida como um apaziguador.

Henriques et al. (2015), a partir de entrevistas com mães de crianças obesas, apontaram para as dificuldades de separação dessas mães em relação aos seus filhos, bem como as dificuldades dos pais (masculinos) de se colocarem como figuras de interdição. Elas consideraram que quando a mãe deposita suas próprias expectativas na criança, com prejuízos no reconhecimento da individualidade dela, em resposta, o comer compulsivo pode surgir como uma tentativa do filho de atender às expectativas maternas, como se tivesse se apropriando daquele alimento, mas sem perceber sua real necessidade.

Sobre o pai, embora alguns estudos que investigam o comportamento alimentar discutam sobre características dele que influenciam nos hábitos alimentares dos filhos, são raros aqueles que abordam diretamente sua perspectiva, investigando apenas as representações da prole sobre sua relação com ele (Wong et al., 2017). Além disso, Davison et al. (2017) destacaram que tanto nos estudos observacionais sobre parentalidade e obesidade infantil, quanto nas propostas de intervenção, a grande maioria dos participantes é composta pelas mães, apesar do atual reconhecimento sobre o aumento do envolvimento paterno no cuidado dos filhos (Vieira \& Nascimento, 2014; Jader \& Botolli, 2011; Amazonas \& Braga, 2006).

Para Davison et al. (2017), a relevância da participação paterna para uma boa qualidade da alimentação dos filhos se dá desde o período do pré-natal, enfatizando a necessidade do desenvolvimento de intervenções junto à família que assumam primeiramente um caráter preventivo. De acordo com Davison et al., o pouco envolvimento do pai durante a gestação está associado com o baixo peso do bebê ao nascer, a redução do período de amamentação e o acentuado ganho de peso na infância. Wong et al. (2020) acrescentaram que a importância da função paterna se intensifica com o decorrer do crescimento da criança, já 
que o fato do pai levar o filho para passear ou brincar, por exemplo, esteve vinculado à menor incidência da obesidade nas crianças.

No que se refere aos filhos, Zeller et al. (2007) verificaram que crianças obesas se percebem como pertencentes a famílias menos coesas, nas quais a união conjugal se mostra enfraquecida e onde são encontrados vários estressores parentais. Sousa (2008) observou que estudantes portugueses se percebiam mais "gordos" quando eram provenientes de famílias que enfrentavam maiores conflitos; porém, não foi encontrada correlação entre IMC e funcionamento familiar.

Assim como a dificuldade dos pais de se organizarem emocionalmente pode interferir na alimentação dos filhos (Foster et al. 2020; Sagui-Henson et al., 2020), o excesso de peso dos últimos pode originar prejuízos emocionais aos pais (Lydecker et al., 2020). Em ambas as situações, percebe-se a necessidade de avaliação e de oferta de suporte à família de modo sistemático nos serviços especializados em obesidade. Todavia, são raros os tratamentos, sobretudo de obesos adultos, que consideram os familiares como parte fundamental das terapêuticas desenvolvidas (Wong et al., 2017). Quando os familiares são incluídos, com frequência, o objetivo é propor mudanças na sua rotina alimentar, com pouca reflexão sobre o seu sofrimento (Bean, et al., 2020). Bean et al. (2020) destacaram que além de a maior parte das estratégias terapêuticas não incluírem a família, quando isso acontece, elas raramente avaliam a eficácia das suas intervenções. Destaca-se que, ao incluir a família, os estudos apontam para a importância de se considerar a complexidade que envolve a relação entre funcionamento familiar e obesidade (Henriquest et al., 2015). Nesse contexto, a psicanálise emerge como uma das possíveis lentes que auxiliam na compreensão dessa vasta teia de relações. Assim, o próximo tópico trará informações sobre como o referencial teórico adotado no presente estudo pode colaborar para a melhor compreensão do tema.

\subsection{Marco teórico}

\subsubsection{Contribuições da psicanálise para a compreensão das relações familiares}

O funcionamento familiar é alvo de estudos psicanalíticos desde a sua origem, tendo como o seu marco inicial os estudos freudianos acerca do complexo de Édipo. Nesse primeiro momento, a preocupação de Freud era direcionada ao modo como a criança organiza a expressão das suas pulsões de morte e vida em relação às figuras parentais (Freud, 
1924/2011). Portanto, o foco estava no indivíduo e no modo como ele se relaciona com o ambiente familiar.

Posteriormente, Melanie Klein aprofundou a investigação das vivências infantis em etapas precoces do desenvolvimento, contribuindo para a compreensão de funcionamentos psicóticos e fronteiriços (Cintra \& Figueiredo, 2004; Klein, 1930/1996). Segal (1963/1975), ao discorrer sobre teoria kleiniana, considerou que o valor do ambiente para tal autora está relacionado com o significado atribuído a ele pela criança, a partir de suas fantasias inconscientes. Assim, embora Klein não desconsiderasse as influências do funcionamento familiar real no desenvolvimento emocional infantil, seu interesse principal concentrava-se no exame dos objetos internos do indivíduo e como eles se relacionam entre si para compor as suas fantasias inconscientes (Zimerman, 1999).

Autores mais recentes como Bion (1962/1991) e Winnicott (1945/2000), ampliaram os estudos dos seus antecessores, atribuindo maior destaque à necessidade de investigação sobre como o ambiente familiar real se apresenta à criança. Bion segue a preocupação kleiniana no que se refere ao estudo dos objetos internos, bem como a freudiana sobre a existência de pulsões, enfatizando o estudo das pulsões destrutivas; porém, ele se preocupa também com a figura da mãe real. Para Bion, as fantasias inconscientes refletem o modo como ambiente real se apresenta (Zimerman, 2004).

Winnicott (1971/1975), por sua vez, afirmou que o indivíduo tem uma predisposição inata ao desenvolvimento, porém a teoria do amadurecimento emocional proposta por ele ressalta a necessidade de um ambiente que seja facilitador, ou "suficientemente bom", para que a evolução seja possível. Assim, o papel atribuído ao meio na obra winnicottiana foi inovador dentro da perspectiva psicanalítica construída até então.

A expansão do pensamento psicanalítico aponta, portanto, para a necessidade de atenção para além do indivíduo isoladamente. Atualmente, embora ainda de modo tímido, existe a preocupação em garantir que esse olhar para o ambiente externo não fique restrito à figura da mãe (Costa, 2014). A teoria winnicottiana, por exemplo, apesar de garantir um papel de destaque à função materna, propõe que, a cada etapa do amadurecimento, o pai assume funções cruciais no cuidado dos filhos, influenciando seu desenvolvimento desde muito antes da vivência do Complexo de Édipo (Fungêncio, 2007). Para Winnicott (1969/1994), a influência paterna acontece mesmo sem que a criança tenha contato direto com o pai, uma vez que ele participa, por exemplo, da realidade interna da mãe que é compartilhada com o bebê.

Além das figuras parentais, o desenvolvimento da psicanálise expandiu o horizonte para o estudo das gerações anteriores (Valdanha et al., 2013). Nesse cenário, a obra de Eiguer 
(1985) se destaca pelas contribuições acerca da transmissão psíquica transgeracional, caracterizada por reconhecer que, nas relações familiares, há forças psíquicas inconscientes construídas ao longo do trabalho de sucessivas gerações. A dinâmica familiar se constitui a partir da integração dessas forças, de modo que o papel assumido por cada integrante influencia a família como um todo. Observa-se, portanto, a construção de um espaço simbólico, no qual circulam conflitos e angústias que rondam as vivências de todos os membros da família.

Roudinesco (2002) considerou que as intensas mudanças vivenciadas pelas famílias na contemporaneidade, sem espaços para a elaboração, colaboram para a erupção de feridas íntimas, traumas e mutilações emocionais que resultam em um sofrimento por vezes silencioso. Consequentemente, são criados sintomas familiares, porém, com frequência, apenas um dos membros se torna porta-voz e evidencia conflitos até então mascarados no interjogo das relações familiares, denúncia que pode culminar no desenvolvimento de um quadro patológico no delator (Soifer, 1980; Meyer, 1987).

Nesse contexto, Gomes (2013) destacou as transformações experienciadas pelo feminino e suas repercussões na dinâmica familiar desde a inauguração do pensamento psicanalítico. A origem da psicanálise tem como base um período no qual a mulher assumia uma posição submissa em relação ao homem, a identidade feminina era equiparada à maternidade e a sexualidade deveria ser destinada à procriação. A genialidade de Freud foi justamente compreender que essa castração imposta à mulher estava na origem dos sintomas histéricos (Freud, 1920/1996).

Depois de mais de um século, a mulher contemporânea conseguiu adentrar em outros espaços além da vida doméstica, porém, segundo Gomes (2013), é uma "mulher em conflito entre os papéis conquistados no mundo masculino e a nostalgia do papel de grande mãe mítica, sábia, generosa e transmissora de afeto" (p. 181). Na perspectiva de Gomes, a herança dos conteúdos transmitidos entre as gerações contribui para que, mesmo com a conquista de maior liberdade, a angústia de castração se mantenha.

As imposições na manifestação da sexualidade feminina influenciam o masculino e a família como um todo, de modo que as relações familiares se tornam rodeadas por tabus que alimentam a alienação do próprio corpo. Essa visão da feminilidade colabora para a construção de vínculos "em que a escolha de parceiros fica determinada por motivações inconscientes da ordem do recalcado em ambos" (Gomes, 2013, p. 182).

Nesse cenário, os relacionamentos se tornam palco para a revivência dos conflitos edípicos e, em uma posição de dependência, espera-se que o companheiro assuma 
características associadas às funções parentais, enquanto a conjugalidade permanece em segundo plano ou sequer é alcançada, conforme explica Gomes (2013):

A busca empreendida por mulheres passivas/castradas no encontro de parceiros ativos/fálicos liga-se a uma identidade feminina dependente emocionalmente da força e do poder do homem, ainda nos dias atuais. Quando o cônjuge não corresponde a esse desejo de completude inconsciente da parceira, temos um fator preponderante no surgimento de determinados conflitos conjugais (p. 188).

Os pais nem sempre apresentam recursos afetivos para exercer todas as funções atribuídas a eles, assim como os filhos podem não apresentar mecanismos defensivos suficientemente eficazes para superar as barreiras encontradas ao longo do desenvolvimento (Soifer, 1980). O casamento das limitações parentais com as do filho pode colaborar para que o processo de individuação do último seja extremamente angustiante para a família como um todo, além de resultar no pouco envolvimento em relações além do âmbito familiar (McDougall, 1986/2000). Como resultado, muitas famílias vivenciam angústias primitivas, principalmente durante a adolescência dos filhos, quando se percebe o aumento da incidência da obesidade e de transtornos alimentares.

A partir das considerações sobre família e psicanálise, o próximo tópico aborda como todo esse emaranhado de relações exerce influência nas características e consolidação da estrutura de personalidade do indivíduo, principalmente a partir do olhar de Bergeret (1988). A estrutura de personalidade está relacionada com o modo como o indivíduo ver a si e se relaciona com o mundo, dessa forma, está intimamente associada ao modo como suas relações familiares são constituídas e com a sua relação com a alimentação, aspectos que aprofundados a seguir.

\subsubsection{As estruturas de personalidade e as organizações limítrofes}

Durante cada etapa do desenvolvimento, a família assume função singular para auxiliar o indivíduo na busca por mecanismos defensivos eficazes para o enfrentamento de ansiedades diante das barreiras encontradas na vida real e psíquica. Bergeret (1988), baseado nas contribuições freudianas sobre o desenvolvimento psicossexual humano, sustenta que a personalidade do indivíduo se organiza de modo a encontrar um equilíbrio perante as angústias e conflitos vivenciados ao longo da sua trajetória. 
A maneira como os elementos da personalidade são organizados culmina na consolidação ou não de uma estrutura de personalidade. Nas palavras de Bergeret (1988), “em psicopatologia, a noção de estrutura corresponde àquilo que, em um estado psíquico mórbido ou não, é constituído pelos elementos metapsicológicos profundos e fundamentais da personalidade, fixados em um conjunto estável e definitivo" (p. 50). Para ele, os principais elementos da personalidade que auxiliam na compreensão das estruturas de base são: natureza da angústia; nível de regressão da libido e do ego; modo relacional; natureza do conflito; gênese das relações familiares e principais defesas.

A partir dessa definição de estrutura e da concepção freudiana de psicopatologia, Bergeret (1988) considerou a existência de duas grandes estruturas: a psicótica (que se divide em esquizofrênica, paranoica e melancólica) e a neurótica (que se divide em obsessiva, histérica de conversão e histérica de angústia).

A consolidação das estruturas psicóticas está relacionada com o enfrentamento de privações $\log$ o no início da vida, o que resulta na fixação da libido em etapas precoces do desenvolvimento (oral I e II e anal I) (Bergeret, 1988). Nesse momento inicial, a principal função atribuída à família é auxiliar no processo de integração de si e no reconhecimento do outro (Lisboa \& Féres-Carneiro, 2015). Quando o ambiente externo não atende a esses quesitos por se mostrar pouco continente às manifestações pulsionais da criança, o real passa a ser percebido como ameaçador, precisando ser negado. Assim, o principal conflito vivenciado pelas estruturas psicóticas está relacionado com a manifestação das pulsões versus a realidade que se opõe.

Grassano (2012), com base nos pressupostos kleinianos, explica que a origem do funcionamento psicótico está na "interação entre um montante exagerado de inveja constitucional e a presença de uma mãe, ou substituto, incapaz de empatia com as necessidades biológicas e psicológicas da criança" (p. 23). Observa-se, portanto, o casamento entre aspectos constitucionais do bebê e as limitações da mãe. Para Grassano, Bion (1991) amplia esse conceito e considera a existência de uma mãe que, por não conseguir conter o medo de aniquilamento da criança, despoja-o do seu desejo de viver, já que auxiliar o filho no enfrentamento do medo de destruição tem como consequência principal estimulá-lo a buscar pela vida.

Para Bion (1991), perante a intensidade do sofrimento psíquico desencadeado pela falta de estímulo à sobrevivência, defensivamente, o bebê inicia uma série de ataques ao próprio psiquismo, direcionados a, conforme explica (Grassano, 2012, p. 23), “toda função 
psíquica capaz de estabelecer um elo com a realidade externa e interna numa tentativa de evitar a dor, mas à custa da destruição do aparelho psíquico”.

Bergeret (1988) explica que os escassos recursos para se reconhecer como unidade fazem com que a principal fonte de angústia na estrutura psicótica seja justamente a de fragmentação. Dessa forma, diante da dificuldade de contato com a realidade e a confusão entre os elementos internos e externos, os mecanismos defensivos utilizados têm como função principal a busca por estratégias alternativas de garantir o equilíbrio, via a construção de uma realidade própria, na qual a existência seja possível. A partir desse objetivo, entre as defesas utilizadas de modo mais intenso no funcionamento psicótico, encontram-se a negação primária e condensação, além de outras que implicam na negação e distorção da realidade, mas possibilitam a amenização do sofrimento (Bergeret, 1988).

Dentre as subestruturas psicóticas, a esquizofrênica é a mais regredida do ponto de vista libidinal e a que apresenta prejuízos mais intensos no desenvolvimento do ego. Já a paranoica, por outro lado, está relacionada com um menor nível de regressão da libido, mas apresenta o ego menos desenvolvido do que a melancólica. Nesta última, o ego conseguiu atingir um nível de maturação superior às outras subestruturas da mesma linhagem, porém é surpreendido pela experiência de uma perda concreta do objeto que não havia sido diferenciado totalmente do eu, em um período no qual ainda não há recursos suficientes para a vivência do luto, o que provoca acentuada regressão da libido (Bergeret, 1988).

Para Grassano (2012), a superação desses conflitos primitivos do desenvolvimento, que leva ao alcance da percepção de si como unidade e, consequentemente, à diferenciação entre objetos internos e externos, permite o ingresso no funcionamento neurótico. Assim, nessa linhagem, é possível o estabelecimento de relações objetais continentes, além do desenvolvimento da capacidade de simbolização:

Esses objetos internos diferenciados dos objetos externos ao ego são motor e, ao mesmo tempo, parte do desenvolvimento correlato de funções psicológicas que determinam mudanças qualitativas na vida mental. A passagem para níveis neuróticos supõe a mudança de um funcionamento mental com predomínio de mecanismos violentos de identificação projetiva evacuativa, equação simbólica e pensamento concreto para um crescente desenvolvimento das funções de percepção e diferenciação da realidade (Grassano, 2012, p. 22).

De acordo com Freud (1925/2011), após o estabelecimento da relação eu-outro, o próximo passo é a inclusão do terceiro elemento na relação dual estabelecida com a figura materna, quando se adentra no universo edípico. $O$ acesso à triangulação permite a organização da personalidade sob o primado da economia genital e a construção do superego, 
propiciando a emergência do impasse entre as exigências superegoicas e a satisfação dos desejos, conflito que caracteriza as estruturas da linhagem neurótica.

As imposições superegoicas desencadeiam o medo de punição caso os desejos sejam expressos, ou mesmo simplesmente descobertos, principalmente aqueles de natureza sexual. A manifestação pulsional, portanto, é , o que desperta intenso sofrimento. Assim, a principal fonte de angústia na estrutura neurótica é a de castração. Nesse contexto, todo o esforço defensivo direciona-se ao controle da manifestação pulsional para evitar a punição; para isso, os desejos são recalcados, na tentativa de conter o sofrimento causado pela sua não concretização (Bergeret, 1988).

Nesse momento, para o enfrentamento do sofrimento suscitado pelos novos impasses, a família continua assumindo papel de destaque e especialmente o pai adquire novas funções, relacionadas tanto à necessidade de se mostrar como figura de interdição e auxiliar na introjeção dos elementos que irão compor o superego, quanto de facilitar a expressão criativa do filho, conforme descreveu Winnicott (1969/1994). Sobre o assunto, Fungêncio (2007) explica:

O pai, homem real, ao mesmo tempo em que aceita a rivalidade, não desautorizando, nem desmerecendo a fantasia, faz a sua parte e realiza o ato objetivo de intervir na consecução dos desejos da criança, impedindo, por exemplo, que esta, sistematicamente, durma com a mãe na cama do casal. Mas, ao mesmo tempo em que intervém, podendo até zangar-se, ele continua cuidando da criança, como sempre o fez, a partir da real maturidade dela (p. 118).

$\mathrm{Na}$ estrutura neurótica, a principal defesa, o recalque, ao reprimir e conduzir os afetos para outro plano, marca a divisão da realidade psíquica em consciente e inconsciente (Quinodoz, 2007). Contudo, a barreira construída entre essas duas instâncias é permeável, uma vez que os mecanismos defensivos empregados ao mesmo tempo em que afastam o conteúdo pulsional interditado, institui seus representantes, permitindo ao ego manter o contato com as fantasias e as lembranças reprimidas (Grassano, 2012).

A primeira e mais regredida entre as subestruturas neuróticas é a obsessiva, na qual o processo de simbolização fracassa com mais frequência em decorrência de momentos de regressão do ego, quando ocorre uma confusão circunscrita entre ato e pensamento, sempre associada ao conteúdo recalcado (Bergeret, 1988). Apesar do acesso ao primado genital, na subestrutura obsessiva ocorrem fixações na fase anal II, que se refletem na construção de relações marcadas pela tentativa de domínio, com o intuito de manter o objeto próximo, 
porém a uma certa distância que impeça o investimento libidinal, estratégia que culmina no empobrecimento das trocas afetivas.

Nessa subestrutura, além do recalque já mencionado, o afeto é isolado e religado a outro representante, principalmente nas obsessões, que funcionam como uma punição por, inclusive, pensar nos desejos "proibidos", mas também remetem a eles, o que gera um nível de satisfação, apesar de parcial (Bergeret, 1988). Assim, de modo aparentemente paradoxal, as defesas implicam tanto na vivência de sofrimento, como de prazer (Freud, 1920/1996).

Na segunda subestrutura neurótica, que se divide em histérica de angústia e histérica de conversão, observa-se maior avanço no desenvolvimento libidinal. Não há regressão do ego, o processo de simbolização já está bem desenvolvido e existe uma boa diferenciação entre ato e pensamento. Entretanto, na histérica de angústia, apesar do reconhecimento de que o pensar não implica na concretização do ato, vivencia-se intensa ansiedade diante do receio de que o desejo se realize. Já na histérica de conversão, o medo se intensifica por ter melhor por ter melhor percepção do fato de que pode concretizá-los, pois o temor é de que, ao serem transformados em atos, o controle sobre eles não seja mais possível (Bergeret, 1988).

Em meio a todos esses temores, são implicados mecanismos defensivos que visam evitar a concretização dos desejos, recalcando-os. No caso da subestrutura histérica de angústia, o afeto também é isolado e deslocado para um representante que passa a ser temido e evitado, em um funcionamento fóbico, porém, na medida em que é constantemente lembrado, ele se mantém conservado. Na histérica de conversão, por meio do recalque, a libido deixa de ser investida no objeto e é direcionada ao próprio corpo, caracterizando um processo conversivo. A conversão impede a concretização do ato e a parte do corpo investida se torna um representante simbólico do afeto reprimido, conforme explica Bergeret (1988):

A conversão somática de natureza autenticamente histérica é caracterizada pela focalização, simbolizada a este nível, de um investimento libidinal retirado das representações amorosas (...) Esta focalização somática corresponde, pois, a um deslocamento sobre uma parte do corpo não escolhida ao acaso, mas designada, ao mesmo tempo, por seu valor simbólico e por seu investimento erógeno, por ocasião da passagem neste nível no decorrer da evolução da sexualidade infantil, intervindo também, da mesma forma (porém mais como pano de fundo, do que determinando a escolha direta), a importância revestida por esta região corporal enquanto investimento narcisista, por ocasião da constituição do esquema corporal do indivíduo (p. 111)

$\mathrm{Na}$ estrutura neurótica, apesar do contato com a realidade já ter sido alcançado, também pode acontecer a vivência de momentos de regressão, nos quais se observa episódios circunscritos de distanciamento em relação à realidade e prejuízos no processo de 
simbolização, sobretudo na estrutura obsessiva (Bergeret, 1988). Nas palavras de Grassano (2012), a partir de uma leitura bioniana (Bion, 1991), "toda personalidade, mesmo a mais integrada, mantém áreas de funcionamento psicótico, nas quais os mecanismos de identificação projetiva hostil e desorganizadores dominam" (p. 22).

Ressalta-se que a regressão experienciada na neurose é pontual e está sempre relacionada com a tentativa de amenização da angústia de castração. Assim, apesar da flexibilização, os elementos característicos dessa estrutura permanecem. Todavia, segundo Bergeret (1988), quando os elementos psíquicos não estão organizados de modo estável, a oscilação é mais constante, a ponto de não haver uma consolidação estrutural e emergirem o que o autor considerou como organizações limítrofes, que, como o próprio nome diz, são funcionamentos intermediários entre a neurose e a psicose.

O indivíduo no estado limite passou pela fase oral e a primeira fase do estágio anal sem maiores problemas. Entretanto, na transição entre a segunda fase anal e a genital, o início do contato com as vivências edípicas, por algum motivo, acontece de maneira traumática, com o indivíduo demonstrando ainda não possuir recursos suficientemente maduros para enfrentá-las. Ele, então, suprime essa etapa do desenvolvimento e se insere em uma condição de "pseudolatência" (Bergeret, 1988). A experiência de latência propriamente dita não pode ser alcançada mediante a carência dos elementos que deveriam ser desenvolvidos anteriormente, como o superego, herdeiro do complexo de Édipo (Freud, 1905/2002).

Para Bergeret (1988), o trauma sofrido desencadeia o medo de perda do objeto, com o qual o indivíduo mantém uma estreita relação de dependência, uma vez que a diferenciação eu-outro ainda não foi totalmente alcançada, apesar do ego já demonstrar maior integração do que a existente nas estruturas psicóticas. Nesse cenário, são desenvolvidos mecanismos defensivos que visam, principalmente, garantir a permanência do objeto. Esse funcionamento sustenta a manutenção de relações anaclíticas, uma vez que o investimento da libido em objetos totais ainda não é consistente, principalmente devido à supressão da etapa edípica. Assim, as relações assumem características narcísicas, já que, na verdade, está se investindo em si mesmo, apesar da intensa e aparente busca pelo outro.

Em meio à ausência do superego, o ideal de ego torna-se a instância dominante na tentativa de controle da manifestação pulsional. Entretanto, a partir do objetivo de garantir a permanência do objeto, ele assume um posicionamento rígido e exigente, desconsiderando, com frequência, tanto as limitações impostas pela realidade, quanto as reais necessidades do indivíduo. Desse modo, compreende-se a origem dos principais conflitos vivenciados nas 
organizações limítrofes: a discordância entre as expectativas do ideal de ego em relação à realidade e aos conteúdos pulsionais (Bergeret, 1988).

A busca pelo alcance de padrões idealizados do ideal de ego abre caminhos para a utilização de defesas falso-self, que visam uma adaptação ao meio, mas que acontece de modo superficial e alimenta a insatisfação (Winnicott, 1956/2000). Esse funcionamento prejudica a construção da individualidade e a manifestação criativa, além do fato de que, mesmo com desprendimento de um intenso esforço, a impossibilidade de alcance das altas expectativas do ideal de ego pode resultar em intensificação e sofrimento, resultando, inclusive, em feridas narcísicas e na erupção de sintomas depressivos. Nas palavras de Bergeret (1988),

A organização limítrofe trata-se acima de tudo de uma doença do narcisismo. Superado o perigo de uma psicogênese do tipo psicótico; a relação do objeto permaneceu centrada na dependência anaclítica do outro; o perigo imediato contra o qual lutam todas as variedades de estados limítrofes é, acima de tudo, a depressão (p. 131).

Anzieu (1988b), a partir da sua experiência clínica, também preocupado com a compreensão das inúmeras psicopatologias associadas aos prejuízos na percepção dos limites e na construção da individualidade, cunhou o conceito do "eu-pele", metáfora que visa ilustrar um fenômeno cada vez mais presente na clínica atual: quando o indivíduo, impedido de delimitar o seu "eu", busca ansiosamente por uma "pele" para torná-lo a sua morada.

Nesse sentido, a obra de Anzieu (1988b) retoma a importância da pele para a proteção física e emocional do humano. Esse órgão, desde o início da vida do bebê, tem o papel crucial de realizar a delimitação do seu corpo e, futuramente, auxiliar na delimitação do psiquismo, uma vez que é a fonte principal de contato com o meio, o que é essencial para o processo de individuação. Na medida em que a mãe manuseia fisicamente a criança, por exemplo, ela a auxilia na compreensão dos seus limites e na decodificação das suas sensações, como no reconhecimento e localização da dor.

A parte do eu que se encontra na pele é fundamental no início e continua atuante durante toda vida do ser humano. Dentre as suas funções, destaca-se a oferta de sustentação ao psiquismo. A patologia se instala quando o acesso aos conteúdos psíquicos fica restrito e o contato tanto com o interno, quanto com o externo torna-se superficial, baseado quase que exclusivamente na primitiva organização eu-pele, como acontece com o bebê (Anzieu, 1988b). 
Nesse cenário, o corpo físico se transforma em palco de manifestações afetivas de diferentes ordens, de modo pouco simbolizado, sendo o principal instrumento de comunicação com o meio, em um posicionamento bastante imaturo (Anzieu, 1988b). As necessidades físicas se confundem com as psíquicas, condição propícia para o desenvolvimento das doenças psicossomáticos. Na mesma linha de pensamento, a visão winnicottiana explica que o fato do corpo e a psique funcionarem de modo dissociado e desintegrado permite que o primeiro seja usado como instrumento de busca por satisfação das carências psíquicas, como acontece, por exemplo, no comer compulsivo (Winnicott, 1964/1994).

É necessário frisar que o sintoma psicossomático se diferencia do processo que enraíza a conversão, característico da histeria de conversão, embora ambos utilizem o corpo como porta-voz dos conflitos vivenciadas. Diferente do que acontece na neurose, a doença psicossomática, frequente nos estados limítrofes e em outros funcionamentos mais primitivos, ocorre quando a integração do self ainda não foi concluída, o que não permite conquistar a simbolização, habilidade fundamental para a realização da conversão. Além disso, a última tem como intenção, sobretudo, evitar o investimento da libido no objeto desejado, deslocando-a para seu representante no corpo (Bergeret, 1988). Já na doença psicossomática, o objeto sequer é reconhecido totalmente e o sintoma visa, principalmente, a busca de contenção para auxílio no processo de integração, sendo que apenas posteriormente será possível pensar no alcance genuíno da capacidade de investimento no objeto como um todo.

Na perspectiva de Mandelbaum (2012), nas famílias contemporâneas a dificuldade de delimitação do próprio e faz com que as diferenças entre os papéis que cada membro assume dentro do grupo se reduzam. Em outras palavras, a falta de compreensão sobre as funções que os diferentes membros exercem nas famílias "não permite uma identificação estável do que é ser adulto ou ser criança, pai ou filho, homem ou mulher” (p. 58). Para Mandelbaum, essa falta de limites está relacionada com padrões estéticos divulgados pela mídia que colaboram para a ampliação do "narcisismo de cada um e dificulta o reconhecimento das diferenças sexuais e geracionais" (p. 65).

$\mathrm{Na}$ mesma vertente, Gabbard (2006) considerou que, na atualidade, os estímulos à competitividade, à valorização da maior capacidade produtiva e ao excesso de autocuidado alimentam as elevadas expectativas do ideal de ego e, consequentemente, o estabelecimento de relações de cunho narcisista, o que, no âmbito familiar, eleva o distanciamento afetivo entre os membros.

Gabbard (2006) lembrou que para a identificação de aspectos psicopatológicos da personalidade é necessário considerar as diferenças individuais, as relações de trabalho e 
principalmente as características socioculturais. Desse modo, a simples presença do sintoma não garante o diagnóstico, uma vez que um determinado comportamento para uma determinada pessoa pode ser fruto de um funcionamento psicopatológico, enquanto para outra ele não tem esse sentido.

Sobre esse assunto, com base na sua visão de estruturas de personalidade, Bergeret (1988) considerou que entre a normalidade e a patologia existe uma barreira muito tênue. Para ele, a emergência do sintoma está relacionada a uma descompensação do equilíbrio conquistado pela organização dos elementos da personalidade em uma estrutura, em decorrência de falhas no sistema defensivo. Contudo, ressalta-se que, na perspectiva de Bergeret, mesmo diante dos riscos de desequilíbrio, depois de consolidada a estrutura, seus principais elementos constitucionais se mantêm, como a natureza da angústia.

Com base nessas contribuições psicanalíticas sobre a natureza e a dinâmica das relações familiares e sobre a constituição da organização da personalidade, elegemos como principal referencial teórico deste estudo a perspectiva winnicottiana da psicopatologia e do amadurecimento emocional, devido à preocupação especial desse autor em considerar a importância do ambiente familiar para o desenvolvimento psíquico do ser humano (Winnicott, 1969/1994). Esse prisma teórico pareceu-nos particularmente profícuo para compreendermos a psicodinâmica individual e o processo de constituição da personalidade nos casos de adolescentes e jovens adultos obesos, conforme promovidos e sustentados pelos elementos componentes das suas dinâmicas familiares, entre eles a personalidade dos pais. Nesse contexto, essa teoria nos permitirá abordar os fatores profundos, latentes, envolvidos no favorecimento, por parte da família, dessa patologia que se tornou epidêmica, concorrendo para uma ampliação do conhecimento sobre os aspectos psicológicos e familiares envolvidos em sua produção e manutenção. Diante disso, o tópico seguinte é destinado a uma exposição das formulações winnicottianas sobre o amadurecimento emocional.

\subsubsection{A teoria winnicottiana do amadurecimento emocional}

Com base no pressuposto de que o homem necessita de cuidados ambientais para se desenvolver, a teoria do desenvolvimento emocional elaborada por Winnicott (1971/1975) considera que o bebê nasce em uma situação de Dependência Absoluta em relação ao meio. Com o decorrer do desenvolvimento, a dependência reduz, embora os cuidados ambientais sempre continuem necessários (Dias, 2003). 
Ao nascer, o bebê ainda não é capaz de fazer uma diferenciação eu/não-eu. É a partir dos cuidados recebidos pelo ambiente que ele começa a construir seu próprio self e a se diferenciar do meio ao redor. Self é um conceito fenomenológico usado para definir a posição teórica que origina o gesto espontâneo e a criatividade primária (Winnicott,1945/2000). O potencial para constituição do self já é herdado pelo indivíduo, cabe apenas ao ambiente auxiliá-lo a amadurecer. O self verdadeiro torna-se possível quando se inicia a organização mental, ou seja, para a sua constituição exige mais do que simplesmente a experiência sensório-motora. Torna-se necessário um ambiente que lhe ofereça suporte suficiente para conduzir ao acesso aos processo mentais.

Winnicott (1971/1975) nomeou de holding e handling os cuidados destinados à criança pelo ambiente. O holding se refere a todos os cuidados despendidos para oferecer continência à criança. Handling seria a manipulação física do bebê durante seus cuidados, ou seja, o contato físico (Dias, 2003).

O ser humano, desde o nascimento, precisa realizar três tarefas fundamentais para a constituição do self: a integração (percepção integrada de si); a personalização (percepção da localização do self dentro do corpo) e a realização (possibilidade de reconhecimento da realidade externa com suas características de tempo e espaço). Esses três processos acontecem durante toda a vida, e apresentam características específicas de acordo com cada etapa do amadurecimento emocional (Winnicott, 1945/2000).

Caso o ambiente não consiga auxiliar o bebê na oferta desses cuidados iniciais, essenciais par a construção do self, além do próprio risco de morte e do desenvolvimento de psicoses, pode ser desenvolvida uma defesa que o autor nomeou falso-self (Winnicott, 1983/2008). A principal função dessa defesa é proteger o verdadeiro self do temor de aniquilamento provocado pela falha ambiental. Então o falso-self tem a função de auxiliar na construção de uma postura submissa, que demonstra aceitar as exigências do meio, mostrando-se, aparentemente, adaptado. Nesse contexto, por exemplo, diante de uma mãe que desconsidera as necessidades do filho e passa a cuidar dele a partir das suas próprias necessidades, o bebê protege seu self verdadeiro e passa a agir conforme as necessidades da mãe. Assim, no funcionamento falso-self, diante do retraimento do self, a expressão criativa torna-se prejudicada. $\mathrm{O}$ bebê pode evidenciar raras demonstrações dos seus afetos e pouco investimento em relacionamentos interpessoais, além de poder utilizar defesas maníacas para negar o sofrimento (Winnicott, 1958/2012).

A primeira etapa do desenvolvimento foi denominada por Winnicott (1971/1975) de "Estágio das Experiências Subjetivas ou de Dependência Absoluta". Trata-se do primeiro 
estágio de instituição do self, que só possível de acontecer com a experiência da ilusão. A ilusão refere-se ao período em que o bebê, a partir das experiências sensoriais, cria um campo imaginário, no qual acredita que consegue criar objetos dos quais necessita. Essa experiência é possível quando a mãe o oferece o objeto que deseja, permitindo que a criança tenha a ilusão de que realmente foi o responsável pela sua criança, em uma fantasia de onipotência (Winnicott, 1956/2000).

Destaca-se que, nesse momento, as relações são de ordem subjetiva, uma vez que os objeto são extensão de si para o bebê. É uma relação narcísica, uma vez que além de não haver investimento no objeto, é necessário que a mãe atenda à todas as necessidades do filho. Nesse momento, o pai pode auxiliar temporariamente a mãe nos cuidados com a criança, assim como proteger a dupla mãe e filho de interferências que possam atrapalhar esse processo.

Para que a mãe compreenda e esteja atenta às necessidades do filho conforme esperado nesse estágio, Winnicott (1971/1975) considera que ela vivencia um estado de preocupação materna primária, quando, em um movimento de regressão, ela desloca todos os seus focos de atenção para o bebê, podendo desenvolver um sensibilidade acurada para perceber suas necessidades e atendendo-as assim que deseja, permitindo que ele tenha a experiência de ilusão (Winnicott, 1956/2000).

Nesse primeiro momento, a motilidade é a principal via pela qual a mãe consegue expressar seu cuidado pelo filho, segurando-o no colo, por meio da oferta do handling. A motilidade da criança pode ser expressa por meio da sua avidez, que é diferente de agressividade, já que o bebê ainda não consegue diferenciar seus sentimentos. O ambiente, ao suportar seus ataques, mantendo a experiência de ilusão, permite que a criança inicie a compreensão das suas funções somáticas, somente a partir da elaboração das vivências somáticas, que será possível iniciar o processo de construção da psique.

Com o desenvolvimento da psique, o modo como corpo é percebido também é modificado, através do processo de personalização, descrito anteriormente. Destaca-se, portanto, que, ao longo do desenvolvimento saudável, o indivíduo vivencia uma constante interação entre psique e soma: a psique é construída a partir das experiências corporais, mas o corpo também é modificado com o desenvolvimento dos processos psíquicos. Na existência de falhas na oferta de holding e handling, o indivíduo pode vivenciar um estado de desintegração (Winnicott 1952/2000), que pode ser entendida como um mecanismo defensivo para enfrentar a ausência de um ambiente suficientemente bom. Diferente da não-integração, ela ocorre quando o indivíduo vivenciou momentos de integração. A não-integração diz 
respeito a um estado inicial, quando a constituição do self ainda não se iniciou e ainda não se tem consciência alguma.

Somente no final da etapa de dependência absoluta, que Winnicott (1983/2008) aborda a necessidade do processo de desilusão, quando o bebê está mais seguro de que possui um corpo que pode ser instrumento de transformação do mundo. Quando o processo de desilusão se inicia após a vivência suficiente da ilusão, possibilita que a criança explore o ambiente sem que haja uma perda da sua sensação de ser (1956/2000).

As falhas da mãe, em excesso, quando impedem que ela supra as necessidades básicas da criança, anteriores à vivência plena da ilusão, podem fazer com que o bebê experimente angústias as quais ele ainda não está preparado para suportar. Nesses situações, dentre as consequências possíveis, ele pode se sentir tomado pelo sentimento de privação e o temor de aniquilamento, o que o autor denominou de angústias impensáveis (Winnicott, 1958/2012).

Dentro do seu curso para o amadurecimento emocional, com o início do processo de desilusão, o bebê inicia a segunda etapa do desenvolvimento denominada por Winnicott (1971/1975) como, "Estágio das Experiências Transicionais ou de Dependência Relativa". Nesse estágio, através das falhas da mãe, o bebê entra em contato com um recorte da realidade, observa-se uma melhor diferenciação eu-não/eu, mas que ainda não está totalmente resolvida. Nesse momento, na visão winnicottiana, o objeto não é interno, nem externo, mas se apresenta em um estágio intermediário, que Winnicott denominou de transicional. Esse espaço transicional funcionaria como uma condição preparatória que permite ao bebê participar da realidade compartilhada (Winnicott, 1971/1975).

A transicionalidade possibilita que a criança suporte as falhas maternas, preenchendoas com suas fantasias. Para isso, ela recorta um pedaço da realidade e se apropria dela, onde pode desenvolver um espaço de "faz de conta", no qual é possível brincar, que lhe permite criar os objetos que deseja, iniciando, assim, o processo de simbolização. Nesse período, ele, através do brincar espontâneo, ela consegue continuar a ilusão, porém de modo menos onipotente (Winnicott, 1971/1975).

$\mathrm{Na}$ visão winnicottiana, o brincar se torna facilitado pela presença de um objeto, nomeado objeto transicional, que deve ter características de vitalidade e suporte os investimentos do bebê, sendo resistentes aos seus mais diversos sentimentos. Esse objeto para o bebê pode ser entendido como uma representante da mãe, mas se diferencia justamente por não ser ela, na medida em que reduz sua dependência em relação a ela. Essa experiência que vai auxiliá-lo a enfrentar a transição entre a experiência de onipotência e de realidade compartilhada. 
O objeto para ser considerado transicional, ele não oferece simplesmente conforto, de modo que a criança precisa utilizá-lo de modo criativo e fazendo um uso criativo e pessoal dele. Winnicott (1971/1975) descreve que é a criança que deve escolhe-lo e os pais devem repeitar o uso que ela faz dele. Com o decorrer do desenvolvimento, ele é deixado de lado, mas em momentos de regressão à transicionalidade, pode ser reutilizado.

A transicionalidade permite a experiência da integração, que leva o bebê a perceber que é a mesma pessoa que vive tanto estados tranquilos, quanto estados de excitação, bem como a mãe, que por vezes repudia, é a mesma que ele "ama". Essa ambivalência afetiva o leva a vivenciar o sentimento de culpa e permite que tenha uma experiência compartilhada com a realidade e com os aspectos culturais (Winnicott, 1971/1975).

Nesse período, a função paterna assume papel de destaque, uma vez que se inicia as vivências edípicas, quando a criança começa a perceber que existe uma relação especial entre ela e a mãe. Espera-se que o pai ofereça contenção aos impulsos agressivos do filho direcionados à mãe, acolhendo e, ao mesmo tempo, fornecendo "limites" (Fungêncio, 2007). O pai, então, além de conter os impulsos agressivos, também assume o papel de interditor dos desejos sexuais do filho. Na perspectiva winnicottiana, o pai tem a função de impedir que o filho invista em fantasias desconectadas da realidade (como o persistente investimento libidinal na mãe), sem com isso tolher a criatividade do filho (Fungêncio, 2007).

Conforme a criança consegue ter uma perspectiva mais íntegra de si e do outro, possibilitada pela transicionalidade, Winnicott (1971/1975) considera que ela alcança o Estágio das Experiências Compartilhadas ou Rumo à Independência. Nesse estágio, alcançou maior integração da personalidade e diferenciação eu-não. Ao conseguir diferenciar realidade externa e interna, pode estabelecer vínculos com os objetos construídos por meio da representação simbólica. A criança também alcança melhor capacidade de introjeção da mãe, caminhando rumo à independência em relação a ela.

No que se às suas contribuições para a compreensão da obesidade, Winnicott (1936/2000) destaca que em todas as psicopatologias podem ser encontradas alterações do apetite, mas que o comportamento alimentar é afetado também na saúde. A intensidade dessa afetação depende de como o indivíduo constituiu seu self, podendo levar ou não ao desenvolvimento de psicopatologias graves. Na relação estabelecida no momento da alimentação do filho, é necessário que a mãe enfrente as angústias suscitadas por essa tarefa, como suportar as manifestações da avidez da criança, que podem lhe causar sofrimento, por exemplo, nas ocasiões em que o bebê machuca o seio ao sugá-lo. 
Caso a mãe apresente altos níveis de ansiedade e não tolere os investimentos do filho, ela pode falhar precocemente no oferecimento de holding a ele (Prado, 2013). Ansiosa, ela também pode forçar a sucção de leite sem atentar às reais necessidades da criança. Por outro lado, pode evitar a oferta de alimento ao filho. Em ambos os casos, ela não consegue oferecer a experiência de ilusão plena, mostra-se intrusiva e dificulta que ele alcance a capacidade para a transicionalidade. Diante de uma mãe que falha em oferecer continência para que o filho encontre alternativas para lidar com sua própria avidez, o comer seletivo ou em excesso podem ser estratégias dissociadas de enfrentamento das falhas que aconteceram precocemente encontradas pela criança.

Mishima e Barbieri (2009b), ao investigarem crianças obesas, observaram dificuldades delas para desenvolverem seu potencial criativo, a partir de brincadeiras pouco elaboradas. Elas mostraram que a brincadeira, da mesma forma que a alimentação, pode se tornar compulsiva, repetitiva ou visar o prazer exagerado. Assim, destacaram que, caso o ambiente não se mostre suficientemente bom, o brincar infantil, ao invés de proporcionar uma sensação prazerosa, pode ser uma alternativa de controle das angústias. Mishima e Barbieri sugerem que essas dificuldades na alimentação e no brincar estariam vinculadas à experiência dessas crianças o com pais autoritários, que se mostraram incapazes de suprir necessidades afetivas dos filhos, enquanto, por outro lado, preocupavam-se em demasia com a oferta do alimento concreto. Elas concluíram que a busca por alimento em excesso era uma via de preencher a deficiência do holding necessário e de comprometimentos no processo de ilusão/desilusão. Estabelecido o estado de arte de nosso objeto de estudo, a obesidade, debatidas as suas relações com o funcionamento familiar e expostas as linhas gerais do referencial teórico a ser adotado, é necessário então considerar por quais meios, neste estudo, serão investigadas as características dos participantes e de suas famílias, de modo a permitir o acesso às informações sobre os seus processos inconscientes capazes de favorecer o surgimento e a manutenção dessa patologia. Para tanto, elegemos os procedimentos projetivos como as ferramentas que proporcionarão as condições para tal alcance. Por isso, dedicamos a elas o próximo tópico, que abordará a sua natureza e os seus alcances e limites para o nosso intuito.

\subsection{Avaliação psicológica e métodos projetivos}

De modo resumido, o objetivo mais reconhecido da avaliação psicológica é a análise de informações, obtidas via utilização de técnicas e de procedimentos, que auxiliam na compreensão de aspectos do funcionamento de um indivíduo ou de um grupo e, 
consequentemente, na elaboração de uma hipótese diagnóstica (Hutz, 2015). Faiad et al. (2019) destacaram que as contribuições da avaliação psicológica resvalam em diferentes contextos de atuação do psicólogo, de modo que suas possibilidades de atuação vão muito além da simples testagem e diagnóstico.

Na mesma linha de pensamento, Reppold et al. (2019) lembraram que a avalição não é uma prática reducionista, que visa simplesmente comparar o indivíduo com padrões de conduta considerados normais e, com isso, rotulá-lo a partir de critérios nosográficos. Em vez disso, a prática da avaliação psicológica propriamente dita, que envolve desde o primeiro contato com a queixa até a elaboração do relatório e a realização de encaminhamentos,

trata-se de um processo complexo, dinâmico, circunscrito no tempo e no contexto, que pode ou não incluir a utilização de testes psicológicos, mas que necessariamente envolve a triangulação de informações obtidas por diferentes métodos de investigação, que sejam reconhecidos cientificamente e estejam de acordo com os preceitos éticos e normativos da profissão (Reppold et al., 2020, p. 20).

Acrescenta-se que, durante todo esse processo, é necessário considerar a influência de aspetos históricos, culturais, sociais e contextuais sobre os resultados encontrados, bem como suas interpretações devem ser fundamentadas em referenciais teóricos consagrados e difundidos pela ciência psicológica, o que faz a prática da avaliação psicológica ser definida como essencialmente científica (Reppold et al., 2020). Nesse sentido, apesar de ser reconhecida como uma área de conhecimento científico próprio, ela está vinculada a outras áreas do conhecimento, como a psicologia do desenvolvimento, a psicologia da saúde e a psicologia da educação.

Ressalta-se que a avaliação psicológica, como ciência, encontra-se em acentuada expansão e desenvolvimento. Para Faiad et al. (2019), é o campo da psicologia que tem apresentado maior desenvolvimento científico na atualidade, principalmente devido às investigações relativas aos métodos e técnicas de avaliação. Nesse sentido, a partir do conhecimento de que seu principal objeto de estudo é o processo avaliativo dos constructos e fenômenos de natureza psicológica, o interesse das pesquisas na área podem estar voltados, por exemplo, para o estudo da execução de técnicas avaliativas (prática mais comum no Brasil); a construção de padrões normativos; o desenvolvimento de novas estratégias de análise dos dados ou até mesmo para a construção de novos instrumentos, dentre outras investigações que regam esse fértil campo do ciência psicológica (Reppold et al., 2020). 
No contexto brasileiro, a realização da avaliação psicológica se torna prejudicada mediante a escassez de estudos normativos que amparam a aplicação de muitos instrumentos, além da necessidade da construção de procedimentos próprios, que incorporem as peculiaridades da população local. Nesse sentido, no âmbito da avaliação psicológica nacional, Nakano e Roama-Alves (2019) ressaltaram a relevância do incentivo a (1) pesquisas que promovam a adaptação, normatização e validação de instrumentos; (2) pesquisas direcionadas a populações específicas para a compreensão de singularidades e (3) pesquisas que envolvam a utilização da avaliação psicológica nos diferentes contextos de atuação do psicólogo, nos quais as técnicas possam ser empregadas.

Sobre a padronização dos instrumentos, Nakano e Roama-Alves (2019) consideraram ainda a necessidade de que os estudos brasileiros utilizem amostras que sejam realmente representativas da população nacional, visto que muitas delas contam apenas com participantes da localidade onde o pesquisador atua.

Para Nakano e Roama-Alves (2019), a criação do Sistema de Avaliação de Testes Psicológicos (Satepsi), pelo Conselho Federal de Psicologia (CFP), representou um grande avanço na área da investigação científica em avaliação psicológica do país. O sistema, embora no início tenha provocado a redução da quantidade de instrumentos permitidos para uso, estimulou o desenvolvimento científico: mediante a maior exigência em relação à padronização e validação das técnicas, foi observado um aumento de pesquisas na área, o que fez com que o número de instrumentos devidamente regulamentados para uso no Brasil crescesse consideravelmente nos últimos anos (Nakano \& Roama-Alves, 2019; VillemorAmaral \& Cardoso, 2019).

A partir de um breve olhar para a história do desenvolvimento dos instrumentos de avaliação psicológica, observa-se que o modo como a avaliação é concebida na atualidade, assim como a concepção da área como um campo científico é extremamente recente. Desde antes de Cristo, há relatos de práticas que envolviam a avaliação de fenômenos psicológicos, como os chineses que avaliavam possíveis candidatos a ocuparem cargos importantes no governo, isso em 2.200 a.C. Entretanto, a estratégia de avaliação psicológica como é conhecida na atualidade começou a ser pesquisada somente no início do século XIX (Faiad et al., 2019).

Nesse começo, os estudos se dedicavam quase que exclusivamente à testagem das diferenças individuais, com foco nos aspectos cognitivos do ser humano e o intuito de precisar sua inteligência (Nakano \& Roama-Alves, 2019). Com o avanço das técnicas de avaliação e da psicometria, os instrumentos foram se tornando cada vez mais precisos e 
melhor fundamentados. Entretanto, a subjetividade dos constructos avaliados pelo psicólogo limita a possibilidade de objetividade dos resultados, mesmo na avaliação de aspectos cognitivos, o que provoca questionamentos sobre a validade e os reais objetivos do processo avaliativo em psicologia (Faiad et al., 2019).

Apesar das críticas, o crescimento da área possibilitou que a avaliação avançasse para além do foco da mensuração da inteligência, quando se adentrou em um terreno ainda mais impreciso: a personalidade. Sobre isso, Nunes et al. (2018) ressaltaram que, primeiramente, a avaliação da personalidade se baseou nos mesmos modelos dos instrumentos de avaliação da inteligência estabelecidos até então, com a tentativa de quantificar traços e fatores que determinam as ações e as relações das pessoas. Sob a influência do pensamento positivista e de concepções empíricas da ciência, o objetivo principal da avaliação era obter os resultados mais objetivos possíveis (Formiga \& Melo, 2000).

Com o avanço científico da área e a integração de conhecimentos de diferentes abordagens ligadas à psicologia, as estratégias de investigação da personalidade ampliaram e tornaram o campo da avaliação psicológica ainda mais fecundo. Cunha (2000a) explicou que, durante o século XX, a avaliação psicológica era influenciada pelas correntes de pensamento que enfatizam o estudo do comportamento, do afeto ou da cognição, cada uma com seus instrumentos específicos e com pouca flexibilização. Contudo, atualmente, os desdobramentos científicos conduziram a uma tendência à integração entre as diferentes abordagens e estratégias de avaliação:

A estratégia de avaliação comportamental foi abdicando da simples identificação de comportamentos-alvo, perfeitamente distinguíveis e observáveis, mas numa abordagem muito idiossincrásica, para começar a incorporar modalidades cognitivas e, mesmo, afetivas, apesar das fortes objeções iniciais. Por outro lado, até psicólogos da mais tradicional orientação dinâmica têm, muitas vezes, recorrido a estratégias de outra orientação conceitual, devido a razões práticas ou científicas, neste caso, por vezes, pressionados por membros da comunidade acadêmica para serem mais eficientes, com menos tempo e custo. Também profissionais com referencial cognitivo passaram a lançar mão de técnicas projetivas para entendimento de motivações pessoais e de outros aspectos idiossincrásicos (p. 19)

Sobre o desenvolvimento dos testes de avaliação da personalidade, para Cunha (2000b), a teoria freudiana foi um dos marcos que autorizou a abertura para a investigação de variáveis menos objetivas, como os conteúdos psicodinâmicos:

Freud, que provinha da melhor tradição neurofisiológica, representou o primeiro elo de uma corrente de conteúdo dinâmico, logo seguido pelo aparecimento do teste de 
associação de palavras, de Jung, em 1906, e fornecendo lastro para o lançamento, mais tarde, das técnicas projetivas (p. 24).

Esse contexto abriu as portas para que, em 1921, Hermann Rorschach lançasse um novo método com vistas a auxiliar na compreensão do funcionamento psíquico. De acordo com Pasian e Amparo (2018), a descoberta de Rorschach foi fruto do seu

desejo de identificar características internas de seus pacientes para humanizar e aprimorar seu tratamento psiquiátrico, com base em princípios psicodinâmicos (fenomenológicos e psicanalíticos), conduziu ao desenvolvimento do "método de interpretação de formas fortuitas", mundialmente reconhecido como "Psicodiagnóstico de Rorschach", válido e preciso em diferentes contextos socioculturais até na atualidade (p. 339).

$\mathrm{O}$ instrumento alcançou significativa popularidade alguns anos mais tarde, principalmente nas décadas de quarenta e cinquenta (Cunha, 2000b). Esse momento da história da avaliação psicológica é descrito por Cunha como o "período áureo" dos métodos projetivos, no qual a psiquiatria demonstrou intensa valorização pela compreensão psicodinâmica do ser humano. Nesse contexto, o Teste de Rorschach e o Teste de Apercepção Temática (Murray, 1943/2005) se tornaram os mais conhecidos entre os métodos difundidos até então, que tinham em comum o fato de permitir o acesso e a compreensão de conteúdos inconscientes da personalidade.

Para Villemor-Amaral e Cardoso (2019), a característica que unifica os métodos projetivos é que eles exigem a execução de tarefas vagas ou ambíguas a partir de instruções abrangentes, estimulando o examinando a recorrer aos seus próprios referenciais para oferecer uma resposta que contém, desse modo, elementos reveladores do seu funcionamento. De acordo com as autoras, o termo projetivo, consagrado pelas diferentes instituições internacionais dedicadas ao estudo e divulgação desses métodos, tem sido questionado, visto que as respostas oferecidas pelo participante não necessariamente fazem uso da projeção, no sentido estritamente psicanalítico do termo, apesar de revelarem a sua marca.

Barbieri (2017), com base nas ideias de Anzieu (1988a), considerou que na Psicologia, o termo projeção pode assumir três sentidos distintos, o que desperta essa confusão. A palavra se refere ao mecanismo defensivo que visa expelir um conteúdo repudiado da personalidade e depositá-lo no outro; também pode caracterizar o espelhamento de elementos da personalidade em algo externo e, por último, pode aludir ao movimento de exposição de conteúdos latentes e interiores, como em um raio-X. 
A partir dessas três possibilidades, na aplicação do instrumento projetivo, o modo como acontece a projeção está relacionado tanto com a tarefa solicitada pela técnica, quando pelo nível de integração da personalidade do indivíduo que a realiza (Barbieri, 2002). Ressalta-se que ele pode ainda não possuir recursos suficientemente maduros, conforme relata Villemor-Amaral e Cardoso (2019), que permitam que a projeção ocorra, porém, de qualquer forma, as técnicas projetivas estimulam a busca por simbolização e, consequentemente, por novas formas de acessar o próprio self.

Apesar da acentuada valorização dos métodos projetivos, as exigências de objetividade, bem como de praticidade no processo avaliativo não cessaram. Além disso, a disseminação do uso desses instrumentos, muitas vezes de modo inadequado, contribuiu para a intensificação das críticas e a redução do seu emprego. Nascimento e Semer (2018), ressaltam que a crescente utilização dos instrumentos de avaliação psicológica, na década de sessenta provocou "uma situação de uso indiscriminado dos testes psicológicos" (p. 313). Nesse cenário, embora o Teste de Rorschach fosse muito prestigiado, não passou ileso de críticas e teve seu uso reduzido.

Todavia, em meio a um contexto científico ainda bastante influenciado pelo positivismo, os estudiosos da técnica desenvolvida por Rorschach contribuíram para que o instrumento se perpetuasse e se mostrasse ainda bastante fortalecido no contexto atual. $\mathrm{O}$ próprio criador do teste faleceu um ano após a sua divulgação (1922), sem poder se aprofundar nas inúmeras possibilidades da sua obra. Entretanto, seus seguidores se dedicaram aos desdobramentos do material, o que culminou na construção de diferentes linhas de estudo, que visam sistematizar sua utilização e interpretação. Dentre os sistemas reconhecidos como responsáveis pela interpretação e disseminação do método, encontra-se a Escola Francesa do Teste de Rorschach, hoje nomeada Escola de Paris, que embasa o presente estudo (Pasian \& Amparo, 2018).

Em sentido contrário ao que se vinha estudando até o momento da sua consolidação, o teste de Rorschach não é um instrumento que impõe ao examinando desempenho máximo ou alta performance, como os testes de avaliação da inteligência. Conforme descreveram Villemor-Amaral e Pianowski (2019), trata-se de um instrumento típico, visto que a exigência é de que o respondente apenas revele elementos sobre como funciona tipicamente no seu cotidiano, ao invés de avaliar suas ações quando é submetido a tarefas que resultam em acertos ou erros.

Enquanto instrumento típico, o Teste de Rorschach possibilita que as características de personalidade do indivíduo sejam acessadas por meio das suas reações ao estímulo e não 
somente pelo conteúdo das suas narrativas. Assim, diferente de técnicas de autorrelato que acessam predominantemente funções verbais e cognitivas, esses instrumentos possibilitam a obtenção de informações que carregam emoções (Villemor-Amaral \& Pianowski, 2019).

Em suma, considera-se que a aplicação sistemática e minuciosa do Teste de Rorschach, a partir da anotação das respostas e das reações comportamentais do examinando enquanto executa a tarefa, permite que o avaliador acesse informações como seus recursos psíquicos associados à produtividade e motivação; sua capacidade de compreender e realizar julgamentos; a representação que tem de si e dos outros; particularidades sobre como se relaciona com os objetos internos e externos e conflitos experienciados que interferem na adaptação à realidade (Villemor-Amaral \& Pianowski, 2019).

Toda essa amplitude de dados que o Teste de Rorschach permite obter torna a utilização do instrumento complexa e sofisticada; por isso o seu ensino demanda uma elevada carga horária, o que abre espaço para equívocos e uso inadequado da técnica. Contudo, ressalta-se que ele é um instrumento extremamente rico e com instruções simples para o respondente compreender, o que amplia o leque de indivíduos que podem ser submetidos a ele. Além disso, Villemor-Amaral e Pianowski (2019) ressaltaram que apesar de não ser o único teste típico para a avaliação da personalidade, ele é exclusivo no sentido de que possui normatização e apresenta validade evidenciadas após sistemáticos estudos científicos. Dessa forma, ele propicia um olhar, respaldado cientificamente, para diferentes aspectos da personalidade do sujeito.

De acordo com Villemor-Amaral e Cardoso (2019), sobre a utilização de métodos projetivos, são aprovados para uso no Brasil pelo Satepsi diferentes sistemas de interpretação dos testes de manchas de tinta (Rorschach e Zulliger) e dos testes de apercepção temática, além dos testes das pirâmides coloridas de Pfister e do Testes de Fotos e Profissões (BBT). Sobre o assunto, as Villemor-Amaral e Cardoso mencionaram que, embora as pesquisas de validação desses métodos sejam mais raras em comparação àquelas que se dedicam aos testes de avaliação da personalidade que utilizam o autorrelato, nos últimos dez anos, foram incluídos no Satepsi pelo menos cinco novos métodos de avaliação de instrumentos projetivos para uso no contexto brasileiro, o que evidenciou o avanço científico nacional na área e fez com que o número de métodos projetivos praticamente se igualasse aos de autorrelato aprovados para a investigação da personalidade.

No que se refere à construção de instrumentos de avaliação projetivos no âmbito nacional que vão além dos testes, destacam-se as Formas Compreensivas de Investigação Psicológica (Trinca, 2013), que começaram a ser desenvolvidas por Trinca em 1972, a partir 
inauguração do Procedimento de Desenhos-Estórias e, posteriormente, o Procedimento de Desenhos de Família com Estórias. Tratam-se de procedimentos, uma vez que, apesar de também serem considerados como projetivos, são diferentes dos testes, principalmente porque não contam com dados normativos para sua correção e interpretação. O método de interpretação sugerido pelo próprio autor dos procedimentos é a livre inspeção do material produzido com a sua aplicação, fazendo alusão ao método de associação livre defendido por Freud (Quinodoz, 2007).

Para Trinca (2013), as Formas Compreensivas de Investigação Psicológica auxiliam na expressão de elementos inconscientes da personalidade relacionados aos conflitos e turbulências experienciadas pelo examinando. Dentre as vantagens desses procedimentos, encontram-se a rapidez e facilidade da aplicação, além do baixo custo e, sobretudo, a "possibilidade de penetração e desvendamento de conteúdos psíquicos relevantes" (p. 13). Nas palavras do Trinca, "em combinação com outros instrumentos e procedimento, como as entrevistas e os testes psicológicos, oferecem informações adicionais e complementares à realização do diagnóstico psicológico" (p. 20).

A partir do conhecimento consideração de que qualquer instrumento de avaliação psicológica possui limitações (Villemor-Amaral \& Cardoso, 2019), a conciliação de diferentes técnicas, bem como a consideração da experiência clínica e o embasamento científico na teoria que fundamenta a análise dos instrumentos, colaboram para a obtenção de um diagnóstico mais coerente e compreensivo em relação aos conflitos vivenciados pelo examinando (Krug et al., 2016).

Da mesma forma que frequentemente os métodos projetivos são criticados pela falta de objetividade, as técnicas de avaliação da personalidade via autorrelato são mais suscetíveis à simulações e manipulações. Nesse cenário, para Villemor-Amaral e Cardoso (2019), ao invés da perpetuação do embate sobre as diferenças existentes entre essas técnicas, é necessário considerar os benefícios do casamento das duas estratégias: "o uso concomitante dos métodos projetivos com outras estratégias avaliativas favorece a obtenção de informações complementares sobre a dinâmica da personalidade da pessoa avaliada" (p. 477). Sobre isso, Loureiro e Romaro (1985) lembraram que, até mesmo entre as técnicas projetivas, existem diferenças no que se refere aos conteúdos da personalidade investigados por cada uma delas, o que reitera a necessidade da avaliação contar com diferentes instrumentos que se somam.

Para facilitar a sistematização do exercício de comparação dos resultados obtidos com as técnicas aplicadas, torna-se necessária a organização dos indicadores dos instrumentos que auxiliam na compreensão das funções que se pretende avaliar. A partir dessa perspectiva, 
Loureiro e Romaro (1985) propuseram protocolos para avaliação da capacidade de produção; ritmo; pensamento; teste do real; controle dos impulsos; relacionamentos interpessoais e mecanismos de defesas, para os seguintes testes: House-Tree-Person (HTP), Desiderativo, Pirâmides Coloridas de Pfister e Rorschach, sendo que o protocolo sugerido para o último foi usado no presente estudo.

O métodos projetivos, em conjunto com outras técnicas de domínio do psicólogo, como entrevistas e a própria observação clínica, constituem-se como as principais ferramentas da avaliação psicológica denominada Psicodiagnóstico, que, diferente da avaliação psicológica, não pode ser realizada sem a utilização de instrumentos de avaliação. Conforme definiu Cunha (2000b),

Psicodiagnóstico é um processo científico, limitado no tempo, que utiliza técnicas e testes psicológicos, em nível individual ou não, seja para entender problemas à luz de pressupostos teóricos, identificar e avaliar aspectos específicos, seja para classificar o caso e prever seu curso possível, comunicando os resultados, na base dos quais são propostas soluções (p. 26).

No cenário do psicodiagnóstico, Heck e Barbieri (2016) destacaram ainda a possibilidade de conciliação da investigação com a intervenção, constituindo-se um espaço tanto avaliativo, quando terapêutico, caracterizando o método denominado Psicodiagnóstico Interventivo. Para Heck e Barbieri a própria avaliação já pode ser terapêutica, uma vez que a regressão provocada pelos métodos projetivos, promove, do mesmo modo que o brincar, o acesso à capacidade para as experiências transicionais e, consequentemente, abre caminhos para a expressão do potencial criativo e fomenta novas possibilidades de simbolização. Assim, o psicodiagnóstico interventivo busca otimizar esses efeitos terapêuticos do processo avaliativo, fazendo uso do movimento regressivo facilitado pela avaliação (Barbieri, 2017).

Na perspectiva de Trinca (2013), no caso de crianças e adolescentes, por exemplo, na clínica, é comum a dificuldade de verbalização das experiências afetivas. Nesse contexto, o emprego dos métodos projetivos, como o Procedimento de Desenhos-Estórias pode facilitar o acesso aos conflitos vivenciados pelo paciente e, por conseguinte, auxiliar no enfrentamento do sofrimento emocional, funcionando como técnicas auxiliares do processo terapêutico.

A partir da compreensão dessas possibilidades de utilização dos métodos projetivos e das contribuições da avaliação psicológica em diferentes contextos de atuação do psicólogo, o presente estudo fez uso de instrumentos dessa natureza como parte fundamental da estratégia metodológica adotada, conforme pode ser observado no método, descrito logo após a apresentação dos motivos que justificam a relevância desta pesquisa e seus objetivos. 


\section{JUSTIFICATIVA}

Os dados apresentados evidenciam a proximidade existente entre os temas "funcionamento familiar" e "obesidade", tanto que o modo como são organizadas as relações familiares constitui-se como um dos fatores que colaboram com o surgimento, manutenção e agravamento do quadro de obesidade em um dos membros da família. Apesar do consenso da relação entre os temas, o modo como ela se constitui é extremamente complexo e exige atenção científica. Essas considerações remetem sobre a necessidade de que o tratamento e os estudos científicos da área englobem também o ambiente familiar.

Considerando que a maioria dos estudos existentes que investigam as relações entre família e obesidade tem como foco a compreensão de aspectos biológicos e hábitos alimentares das famílias de indivíduos obesos, observa-se a escassez de estudos que investiguem conteúdos psicodinâmicos dessas famílias, como é o objetivo do presente estudo. Nos raros estudos encontrados, o enfoque é na obesidade infantil e na relação com a mãe, enquanto as relações familiares na obesidade de jovens adultos e aspectos da relação com a figura paterna parecem ser pouco investigados.

Dessa forma, acredita-se que o estudo, ao contribuir com a compreensão do funcionamento psicodinâmico dessas famílias, bem como ao investigar características de personalidades dos pais de mulheres obesas que podem colaborar com o desenvolvimento de hábitos alimentares inadequados nas filhas, poderá trazer subsídios para o enfrentamento da obesidade de forma mais eficaz, já que esta é considerada como um dos maiores problemas atuais de saúde pública a nível mundial e, portanto, demanda por profissionais e atenção especializados e bem-preparados. 


\section{OBJETIVOS}

\subsection{Objetivo Geral}

Investigar as características de personalidade de mulheres obesas e de seus pais e mães e aspectos dos psicodinamismos familiares, visando averiguar a existência de associações entre essas variáveis e o surgimento ou manutenção do excesso de peso nas filhas.

\subsection{Objetivos Específicos}

(1) Compreender a estrutura e características da personalidade de pais, mães e de filhas com Obesidade;

(2) Compreender aspectos da psicodinâmica familiar a partir da perspectiva dos participantes;

(3) Compreender os relacionamentos familiares que se estabelecem em famílias de adolescentes e jovens adultas com Obesidade;

(4) Compreender as influências da personalidade dos pais e do vínculo familiar no desenvolvimento e manutenção da Obesidade da filha. 


\section{CONSIDERAÇÕES FINAIS}

O presente estudo teve como objetivo investigar aspectos da dinâmica familiar e características da personalidade da tríade composta por pais, mães e filhas obesas, buscando compreender como esses fatores poderiam favorecer o surgimento e a perpetuação do quadro de obesidade nas filhas. Os resultados mostraram que os psicodinamismos conduzem a relações familiares marcadas pelo distanciamento físico e emocional, fruto de uma intensa repressão dos afetos, principalmente aqueles vinculados à experiência da sexualidade.

Os resultados evidenciaram uma relação mãe-filha marcada pela mútua dependência, na qual o alimento media um tipo de vínculo que, embora aparentemente estreito, é fundamentalmente, superficial, no sentido de ser esvaziado de uma verdadeira intimidade. Os pais, por sua vez, também demonstraram recurso intenso à expedientes defensivos repressivos dirigidos aos afetos e à sexualidade. Eles se mostraram também bastante passivos nos relacionamentos familiares e com significativos prejuízos para se posicionarem para as filhas como um modelo de superego integrando características benignas e de interdição face aos afetos edipianos da filha, dificultando o desenvolvimento de uma capacidade de continência dos afetos da parte delas.

Por conta desses funcionamentos, ambos os pais demonstraram significativas dificuldades na oferta de holding às filhas desde o início da vida, não constituindo um ambiente favorável à consolidação do self e à expressão da criatividade primária. Se essas deficiências na relação primitiva com as filhas não foram suficientes para mantê-las em um funcionamento próximo da psicose, elas deixaram cicatrizes que se abriram no momento posterior do amadurecimento emocional concernentes ao segundo e terceiro estágios quando o ingresso na situação edípica fomenta o surgimento de afetos relativamente violentos ligados aos desejos incestuosos e homicidas (Winnicott, 1956/2000). A reativação dessas experiências na adolescência, caracterizada por sua com maior intensidade do que na infância (Aberastury, 1982), amplifica os temores, as angústias e, em consequência, exige maior rigor na aplicação das defesas para o seu controle. No caso das filhas estudadas, a insuficiência da repressão conduz ao recrutamento de outras defesas, inicialmente também de natureza neurótica como o isolamento, o deslocamento e a conversão e, diante da igual insuficiência destas, à regressão e, eventualmente, de modo menos importante, a dissociação e o falso-self.

$\mathrm{O}$ movimento regressivo operado pelas filhas remete-as primordialmente à etapa oral do desenvolvimento psicossexual, promovendo a manutenção de um relacionamento 
infantilizado e dependente com os pais. Trata-se de uma tentativa de escapar das angústias despertadas pela sexualidade genital, sendo a oral percebida como menos ameaçadora, e o vínculo dependente como uma tentativa de restaurar experiências capazes de curarem feridas primitivas. Contudo, o recurso à regressão não é infalível, conforme testemunhado por episódios de impulsividade das filhas em vários contextos, entre eles o alimentar, expresso nesse âmbito como atitudes compulsivas e voracidade.

Essa regressão ao estágio oral e o deslocamento dos desejos genitais para o seu âmbito é sustentado pelas dificuldades dos pais de empreenderem um relacionamento afetivamente próximo com as filhas, conforme descrevemos, fruto das dificuldades deles relativas à integração dos afetos no self. Com isso, os cuidados fornecidos às filhas são sobretudo da ordem concreta, o alimento simbolizando o afeto paterno e materno de que tanto carece a filha.

Os comprometimentos da integração dos afetos no self exibidos pelos pais e mães testemunham a existência de um superego altamente rigoroso, que atua de forma bastante coercitiva seja na esfera da vivência da sexualidade, mas também na da criatividade primária. Nesse contexto, os desejos e pulsões, bem como a impulsividade que tentam conter de maneira austera, são projetados nas filhas. Essa dinâmica pessoal dos pais conduz então a um relacionamento próximo em que o gozo (ou sofrimento) das filhas é o gozo (ou sofrimento) das mães e dos pais, o que de certa forma os aproxima e mantém a relação de dupla (ou tripla) dependência. Por outro lado a mesma dinâmica promove o afastamento entre os familiares, por meio da incompreensão dos pais relativas às condutas e às dores das filhas que, no seu entender, receberam provisões materiais muito melhores do que eles próprios na infância. Portanto, as manifestações sintomáticas das filhas seriam fruto de uma interação com as dificuldades de seus pais e mães, tornando-se ela a porta-voz de insatisfações e angústias vivenciadas por toda a família.

A maioria dos participantes da pesquisa apresentou psicodinamismos da ordem do registro neurótico, contrariando algumas conclusões da literatura sobre uma possível associação entre esse quadro e a organização limítrofe de personalidade (Sansone \& Sansone, 2013). Nesse contexto, o ponto de vista estritamente estrutural parece ser insuficiente para fornece uma compreensão mais abrangente da obesidade, que parece mais ser sustentada, de acordo com os nossos resultados em psicodinamismos vinculados a angústias tanto de castração, mas também de perda do objeto, e a episódios, mais ou menos frequentes de impulsividade que denunciam as deficiências defensivas. Nesses termos, como qualquer outro sintoma, a obesidade pode apresentar, de acordo com o caso, sentidos diferentes e ser 
"construída" de formas diferentes. O que pareceu ser comum entre elas foi a articulação entre os seus psicodinamismos e aqueles dos seus pais e mães na complexa teia que favorece a obesidade e que varia de acordo com cada caso.

Desse modo, o tratamento e a prevenção da obesidade, principalmente por conta das comorbidades que esse quadro apresenta, corre o risco de ser inócuo quando desconsidera os poderosos psicodinamismos individuais do paciente envolvidos no favorecimento dessa patologia, mas também quando negligencia que esse funcionamento psíquico é sustentado por uma trama relacional familiar altamente sofisticada. Sem a atenção a esses alicerces da constituição do self, a adesão a tratamentos médicos é duvidosa e o resultado considerado bem sucedido, a saber, o emagrecimento do paciente, pode provocar descompensações importantes na personalidade dos membros ou mesmo fazer implodir a dinâmica familiar, ou seja, a cura pode ser mais grave que a patologia.

Em suma, as avaliações dos participantes dos três grupos desta pesquisa (pais, mães e filhas), revelaram a vivência de intenso sofrimento, em todos os membros, que constituem o alicerce dos sintomas apresentados pelas filhas, entre eles a obesidade, que são intensificados e alimentados pelos três. Dessa maneira, da mesma forma que não se constrói uma nova casa sem a avaliação das condições de suas fundações, nossos resultados demonstram a necessidade de um olhar profundo e atento aos psicodinamismos individuais e familiares do paciente obeso tanto por razões de eficácia terapêutica, mas também, e sobretudo, éticas. Portanto, nossas conclusões apontam para a necessidade de reflexão sobre estratégias que ofereçam suporte emocional no contexto do tratamento para a obesidade, não somente para o paciente, mas também para a família. Entretanto, as dificuldades que experimentamos ao longo desta investigação para termos acesso aos participantes, principalmente aos pais e mães, revelam os desafios que uma estratégia de intervenção terapêutica que busque incluir as famílias no tratamento da obesidade do paciente deve enfrentar.

Dentre as limitações do estudo, destaca-se que a avaliação foi realizada apenas com parte dos integrantes da família. Considera-se que a inclusão de outros membros, como os irmãos das pacientes, poderia colaborar para uma compreensão ainda mais ampla sobre a dinâmica familiar. Também é necessário ressaltar que, por se tratar de uma pesquisa qualitativa que empregou o método do estudo de caso coletivo, os resultados que encontramos, não permitem generalizações. Entretanto, a riqueza dessa estratégia metodológica é, sobretudo, permitir explorar as singularidades dos indivíduos e fenômenos estudados, o que nos proporcionou, inclusive, concluir sobre a diversidade de ordenamentos da personalidade em que a obesidade pode se desenvolver. Desse modo, foram possíveis 
identificar características semelhantes nos funcionamentos das famílias, mas também as suas peculiaridades, o que permite diferentes olhares sobre os dados encontrados. Nesse sentido, as análises que foram iniciadas, embasadas na teoria na qual esse estudo se sustenta, mostram-se apenas como um recorte e algumas das possibilidades de olhar a amplitude dos resultados encontrados. 


\section{REFERÊNCIAS ${ }^{1}$}

Aberastury, A. (1982). Psicanálise da Criança: teoria e técnica. Porto Alegre: Artes Médicas, 8 edição.

Abram, J. (2000) A linguagem de Winnicott. Rio de janeiro: Revinter.

Aiello-Vaisberg, T. M. J. (2004). Ser e fazer: enquandres diferenciados na clínica Winnicottiana. Aparecida, SP: Ideias e Letras.

Agras, W. S., \& Mascola, A. J. (2005). Risk factors for childhood overweight. Current Opinion in Pediatrics, 17(1), 648-652.

Amazonas, M. C. L. A., \& Braga, M. G. R. (2006). Reflexões acerca das novas formas de parentalidade e suas vicissitudes culturais e subjetivas. Ágora, 9(2), 177-191.

American Psychiatric Association (2013). Diagnostic and statistical manual of mental disorders DSM-V. Washington, DC: American Psychiatric Association.

Anzieu, D. (1988a). Os métodos projetivos. (Trad. Silva, M. L. E.). Rio de Janeiro: Campus.

Anzieu, D. (1988b). O Eu-pele. São Paulo: Casa do Psicólogo.

Barbieri, V. (2013). Laços e embaraços: o Procedimento de Desenhos de Famílias com Estórias na compreensão cruzada dos psicodinamismos de mãe e filha. In W. Trinca (Org.). Procedimento de Desenhos-Estórias: formas derivadas, desenvolvimentos e expansões (pp. 231-276). São Paulo: Vetor.

Barbieri (2017). O psicodiagnóstico interventivo: A família e o psicodiagnóstico como recursos terapêuticos no tratamento de crianças. Novos edições acadêmicas.

Bean, M. K., Caccavale, L. J., Adams, E. L., Burnette, C. B., LaRose, J. G., Raynor, H. A., Wickham, E. P., \& Mazzeo, S. E. (2020). Parent involvement in adolescent obesity treatment: A systematic review. Pediatrics, 146(3).

Bergeret, J. (1988). A personalidade normal e patológica. Porto Alegre: Artes Médicas.

\footnotetext{
${ }^{1}$ De acordo com o estilo APA (American Psychological Association).
} 
Bion, W. (1991). O aprender com a experiência. Rio de Janeiro: Imago. (Trabalho original publicado em 1962).

Bohnert, A. M., Loren, D. M., \& Miller, A. L. (2020). Examining childhood obesity through the lens of developmental psychopathology: Framing the issues to guide best practices in research and intervention. American Psychologist, 75(2), 163-177.

Borsa, J. C., \& Nunes, M. L. T. (2011). Aspectos psicossociais da parentalidade: O papel de homens e mulheres na família nuclear. Psicologia Argumento, 29 (64), 31-39.

Brasil. Ministério da Saúde. (2012). Resolução no 466/12 sobre pesquisa envolvendo seres humanos. Brasília: Conselho Nacional de Saúde.

Camargo, M. A. G. F. (2013). Coping e aspectos psicossociais associados ao tratamento cirúrgico da obesidade mórbida em longo prazo. Tese de Doutorado, Instituto de Psicologia, Universidade de São Paulo, São Paulo.

Chabert, C. (1998). Psychanalyse et méthodes projectives. Paris: Dunod.

Cintra, E. M. U., \& Figueiredo, L. C. (2004). Melanie Klein, Estilo e Pensamento. São Paulo: Escuta.

Costa, L. R. S. (2014). Relação pai-filha no contexto dos transtornos alimentares: uma perspectiva winnicottiana. Dissertação de Mestrado, Faculdade de Filosofia, Ciências e Letras de Ribeirão Preto, Universidade de São Paulo, Ribeirão Preto.

Costa, R. R., Moreira, T. M. M., Florêncio, R. S., Pessoa, V. L. M. P., Cestari, V. R. F., \& Montesuma, F. G. (2018). Excesso Ponderal e fatores associados em mulheres adultas jovens escolares. Revista Brasileira de Enfermagem, 71(6).

Cunha, J. A. (2000a). Estratégias de avaliação: perspectivas em psicologia clínica. In: J. A. Cunha (Org.) Psicodiagnóstico V (pp. 19-22). Porto Alegre: Artes Médicas.

Cunha, J. A. (2000b). Fundamentos do psicodiagnóstico. In: J. A. Cunha (Org.) Psicodiagnóstico V (pp. 19-22). Porto Alegre: Artes Médicas. 
Cury-Jacquemin, R. P. (2012). Padrões normativos do Psicodiagnóstico de Rorschach em adolescentes de 12 a 14 anos. Dissertação de Mestrado, Faculdade de Filosofia, Ciências e Letras de Ribeirão Preto, Universidade de São Paulo, Ribeirão Preto.

Dantas, R. \& Silva, G. (2019). The role of the obesogenic environment and parental lifestyles in infant feeding behavior. Revista Paulista de Pediatria, 37(3), 363-371.

D'avila, H. F., Poll, F. A., Reuter, C. P.; Burgos, M. S. Mello, E. D. (2019). Qualidade de vida relacionada à saúde em adolescentes com excesso de peso. Jornal de Pediatria, 95(4), 495-501.

Davison, K. K., Kitos, N., Aftosmes-Tobio, A., Ash, T., Agaronov, A., Sepulveda, M., \& Haines, J. (2018). The forgotten parent: Fathers' representation in family interventions to prevent childhood obesity. Preventive Medicine: An International Journal Devoted to Practice and Theory, 111, 170-176.

Dias, E. O. (2003). A teoria do amadurecimento de D. W. Winnicott. Rio de Janeiro: Imago.

Durham, E. R. (1983). Família e reprodução humana. In B. Franchetto, M. L. V. C. Cavalcanti \& M. L. Heilbonr (Orgs). Perspectivas antropológicas da mulher (Vol. 3, PP. 15-43).

Eiguer, A. (1985). Um divã para a família (Trad. L. M. V. Fisher). Porto Alegre: Artes Médicas.

Faiad, C., Pasquali, L., \& Oliveira, K. L. (2019). Histórico de Avaliação Psicológica no mundo. In: M. N. Baptista, M. Muniz, C. T. Reppold, C. H. S. S. Nunes, L. F. Carvalho, R. Primi, A. P. P. Noronha, A. G. Seabra, S. M. Wechsler, C. S. Hutz, L. Pasquali (Orgs.). Compêndio de Avaliação Psicológica (pp. 111-121). Petrópolis: Vozes.

Farias, E. S., Moreira, K. F. A., Santos, J. P., Gemelli, I. F. B., Costa, G. M., \& Souza, O. F. (2020). Sobrepeso e obesidade: prevalência em crianças e adolescentes ao Norte do Brasil. Journal of Human Growth and Development, 30(2), 266-273.

Farrell, E. (2004). Obesity: how can we understand it? Free Associations, 11(1), 477-496.

Ferreira, A. P. S., Szwarcwald, C. L., \& Damacena, G. N. (2019). Prevalência e fatores associados da obesidade na população brasileira: estudo com dados aferidos da Pesquisa Nacional de Saúde, 2013. Revista Brasileira de Epidemiologia, 22(E190024). 
Fisberg, M. (2005). Primeiras palavras: uma introdução ao problema do peso excessivo. In Atualização em obesidade na infância e adolescência (pp. 1-10). São Paulo: Editora Atheneu.

Formiga, N. S., \& Mello, I. (2000). Testes psicológicos e técnicas projetivas: uma integração para um desenvolvimento da interação interpretativa indivíduo-psicólogo. Psicologia Ciência e Profissão, 20(2), 12-19.

Foster, B. A., Weinstein, K., Mojica, C. M., \& Davis, M. M. (2020). Parental mental health associated with child overweight and obesity, examined within rural and urban settings, stratified by income. The Journal of Rural Health, 36(1), 27-37.

Francischi, R. P. P., Pereira, L. O., Freitas, C. S., Klopfer, M., Santos, R. C., Vieira, P., \& Lancha Junior, A. H. (2000). Obesidade: atualização sobre sua etiologia, morbidade e tratamento. Revista de Nutrição, 13(1), 17-28.

Freud, S. (1996). Além do princípio do prazer (Trad. Paulo Dias Correa). In: Obras completas: Edição Standart Brasileira. Rio de Janeiro: Imago (Trabalho original publicado em 1920).

Freud, S. (2002). Além do princípio do prazer (Trad. Paulo Dias Correa). In: Obras completas: Edição Standart Brasileira. Rio de Janeiro: Imago (Trabalho original publicado em 1905).

Freud, S. (2011). A dissolução do complexo de Édipo. Edição Standart Brasileira (ESB) das obras completas de Sigmund Freud. Rio de Janeiro: Imago (Trabalho original publicado em 1925).

Fungêncio, C. D. R. (2007). A presença do pai no processo de amadurecimento: um estudo sobre D. W. Winnicott. Dissertação de Mestrado. Pontifícia Universidade Católica de São Paulo, São Paulo.

Gabbard, G. O. (2006). Psiquiatria psicodinâmica na prática clínica (Trad. Maria Rita Secco Hofmeister) ( ${ }^{\mathrm{a}}$ ed.). Porto Alegre: Artes Médicas

Golan, M., Weizman, A., Apter, A., \& Fainaru, M. (1998). Parents as the exclusive agents of change in the treatment of childhood obesity. The American Journal of Clinical Nutrition, 67(1), 1130-1135. 
Gomes, I. C. (2014). Conflitos conjugais e transmissão psíquica geracional: das histéricas de Freud à mulher atual. In T. Féres-Carneiro (Org). Casal e família: transmissão, conflito e violência (pp. 177-190). São Paulo: Casa do Psicólogo.

Grassano, E. (2012). Indicadores psicopatológicos em técnicas projetivas (Trad. Rosângela Dantas) São Paulo: WMG Martins Fontes.

Haslam, D. W., \& James, W. P. (2005). Obesity. Lancet, 366(1), 1197-1209.

Heck, V., \& Barieri, V. (2016). Psicodiagnóstico interventivo. In Hutz, C. S., Bandeira, D. R., Trentini, C. M., \& Krug, J. S. (Orgs.). Psicodiagnótico (pp. 184-193). Porto Alegre: Artes Médicas.

Hennigen, I. (2010). Especialistas advertem: o pai é importante para o desenvolvimento infantil. Fractal: Revista de Psicologia, 22 (1), 169-184.

Henriques, M. S. M. T. et al. (2015). O exercício da função materna em mães de filhos obesos na perspectiva da psicanálise. Revista Latinoamericana de Psicopatologia Fundamental, 18(3), 461-475.

Hirschler, V., Gonzalez, C., Talgham, S., \& Jadzinsky, M. (2006). Do mothers of overweight Argentinean preschool children perceive them as such? Pediatric Diabetes, 7(4), 201204.

Hughes, S. O., O'Connor, T. M., \& Power, T. G. (2008). Parenting and children's eating patterns: examining control in a broader context. International Journal of Child and Adolescent Health, 1(1), 323-330.

Hutz, C. S. (2015). O que é avalição psicológica, métodos, técnicas e testes. In: C. S. Hutz, D. R. Bandeira, \& C. M. Trentini (Orgs.). Psicometria. Porto Alegre: Artes Médicas.

Jader, M. E., \& Bottoli, C. (2011). Paternidade: vivência do primeiro filho e mudanças familiares. Revista Psicologia: Teoria e Prática, 13(1), 141-153.

Jardim-Maran, M. L. C. (2011). O Psicodiagnóstico de Rorschach em adolescentes: normas e evidências de validade. Tese de Doutorado, Faculdade de Filosofia, Ciências e Letras de Ribeirão Preto, Universidade de São Paulo, Ribeirão Preto. 
Kaiser, B. (2008). Troubles du comportement alimentaire. In M. Bouvard (Org.). Échelles et questionnaires d'évaluation chez l'enfant el l'adolescent (pp. 27-46). Paris: Elsevier Masson.

Kalra, G., de Sousa, A., Sonavane, S., \& Shah, N. (2012). Psychological issues in pediatric obesity. Industrial Psychiatry Journal, 21(1), 11-17.

Klein, M. (1996). A importância da formação de símbolos no desenvolvimento do ego. In M. Klein, Amor, culpa e reparação e outros trabalhos (1921-1945). (A. Cardoso, Trad., pp. 249-264). Rio de Janeiro: Imago. (Trabalho original publicado em 1930).

Krug, J. S., Trentini, C. M., \& Bandeira, D. R. (2016). In Hutz, C. S., Bandeira, D. R., Trentini, C. M., \& Krug, J. S. (Orgs.). Psicodiagnótico (pp. 17-20). Porto Alegre: Artes Médicas.

Latzer, Y., \& Stein, D. (2013). A review of the psychological and familial perspectives of childhood obesity. Journal of Eating Disorders, 1(1), 7.

Leonidas, C. (2016). Das (im)possibilidades do feminino: a sexualidade de mulheres com transtornos alimentares na perspectiva das adolescentes, suas mães e seus pais. Tese de Doutorado, Universidade de São Paulo, Ribeirão Preto.

Lisboa, A. V., \& Féres-Carneiro, T. (2015). Acontecimentos Significativos na História Geracional e sua Relação com Somatizações na Família. Psicologia: Teoria $e$ Pesquisa, 31(1), 65-72.

Lydecker, J. A., Park, J., \& Grilo, C. M. (2020). Parents can experience impairment because of their children's weight and problematic eating behaviors. Journal of Adolescent Health, 66(2), 189-194.

Loureiro, S. R., \& Romaro, R. A. (1985). A utilização das técnicas projetivas, bateria de Grafismo de Hammer e Desiderativo como instrumentos de diagnóstico - estudo preliminar. Revista Arquivos Brasileiros de Psicologia, 37(3), 132-141.

Mandelbaum, B. (2012). Família incestuais. Psicologia Clínica, Rio de Janeiro, 24 (11), 55-66.

Martini, M. C. S., Assumpção, D., Barros, M. B. A., Barros-Filho, A. A., \& Mattei, J. (2020). Satisfaction with body weight among adolescents with excess weight: findings from a cross-sectional population-based study. São Paulo Medical Journal, 138(5), 377-384. 
Mc Cully, R. S. (1980). Rorschach - Teoria e Simbolismo. Belo Horizonte: Interlivros.

McDougall, J. (1986). Um corpo para dois. In: J. McDougall, G. Gachelin, P. Aulagnier, P. Marty, J. Loriod, \& J. Caïn (Orgs.), Corpo e história (L. Y. Massuh, Trad.). São Paulo: Casa do Psicólogo.

Mendes, J. O. H., Bastos, R. C., \& Moraes, P. M. (2019). Características psicológicas e relações familiares na obesidade infantil: uma revisão sistemática. Revista da SBPH, 22(2), 228-247.

Meyer, L. (1987). Família: dinâmica e terapia (uma abordagem psicanalítica) (2a ed.) (G. Schlesinger, Trad.). São Paulo: Brasiliense.

Ministério do Planejamento, Orçamento e Gestão. Instituto Brasileiro de Geografia e Estatística (IBGE) (2019a). Pesquisa Nacional de Saúde 2019. Rio de Janeiro: Instituto Brasileiro de Geografia e Estatística.

Ministério do Planejamento, Orçamento e Gestão, Instituto Brasileiro de Geografia e Estatística (IBGE) (2019b). Pesquisa Nacional de Saúde do Escolar 2019. Rio de Janeiro: Instituto Brasileiro de Geografia e Estatística.

Minayo, M. C. S. (2012). Análise qualitativa: Teoria, passos e fidedignidade. Ciência \& Saúde Coletiva, 17(3), 621-626.

Mishima, F. K. T., \& Barbieri, V. (2009a). Saúde feminina: Considerações sobre Psicodiagnóstico Interventivo na obesidade. Mudanças - Psicologia da Saúde, 17(2), 92-100.

Mishima, F. K. T., \& Barbieri, V. (2009b). O brincar criativo e a obesidade infantil. Estudos de Psicologia, 14(3), 249-25.

Murray, H. A. (1943/2005). TAT: Teste de Apercepção Temática. Henry A. Murray e colaboradores da Clínica Psicológica de Harvard, $3^{\text {a }}$ Ed. São Paulo: Casa do Psicólogo.

Nascimento, R. S. G. F., \& Semer, N. L. (2018). O sistema compreensivo de Exner para avaliação pelo Teste de Rorschach. In Hutz, C. S., Bandeira, D. R., \& Trentini, C. M. (Orgs.). Avaliação da Inteligência e da Personalidade (pp. 312-326). Porto Alegre: Artes Médicas. 
Nakano, T. C., \& Roama-Alves, R. J. (2019). Avaliação Psicológica Brasil. In: M. N. Baptista, M. Muniz, C. T. Reppold, C. H. S. S. Nunes, L. F. Carvalho, R. Primi, A. P. P. Noronha, A. G. Seabra, S. M. Wechsler, C. S. Hutz, L. Pasquali (Orgs.). Compêndio de Avaliação Psicológica (pp. 122-132). Petrópolis: Vozes.

Noh, H.-M., Park, J., Sung, E.-J., Ju, Y. S., Lee, H.-J., Jeong, Y.-K., \& Park, K. H. (2020). Family factors and obesity in relation to mental health among korean children and adolescents. Journal of Child and Family Studies, 29, 1284-1292.

Nogueira-de-Almeida, C. A., Del Ciampo, L. A., Ferraz, I. S., Del Ciampo, I. R.L., Contini, A. A., \& Ued, F. V. (2020). COVID-19 e obesidade na infância e adolescência: uma revisão clínica, Jornal de Pediatria, 96(5), 546-558.

Nunes, C. H. S. S., Zanon, C., \& Hutz, C. S. (2018)._Avaliação da personalidade a partir de teorias fatoriais da personalidade. In Hutz, C. S., Bandeira, D. R., \& Trentini, C. M. (Orgs.). Avaliação da Inteligência e da Personalidade (pp. 217-231). Porto Alegre: Artes Médicas.

Pasian, S. R. (2000). O Psicodiagnóstico de Rorschach em adultos: atlas, normas e reflexões. São Paulo: Casa do Psicólogo.

Pasian, S. R., \& Amparo, D. M. (2018). O Teste de Rorschach na perspectiva da Escola de Paris. In Hutz, C. S., Bandeira, D. R., \& Trentini, C. M. (Orgs.). Avaliação da Inteligência e da Personalidade (pp. 339-353). Porto Alegre: Artes Médicas.

Perucchi, J., \& Beirão, A. M. (2007). Novos arranjos familiares: paternidade, parentalidade e relações de gênero sob o olhar de mulheres chefes de família. Psicologia Clínica, 19 (2), $57-69$.

Prado, E. F. A. (2013). A seletividade alimentar e o setting analítico: um estudo de caso sob a ótica da Teoria do Desenvolvimento Emocional de Donald Woods Winnicott. Dissertação de Mestrado, Pontifícia Universidade Católica de São Paulo, Campinas.

Pulgarón, E. R. (2013). Childhood obesity: a review of increased risk for physical and psychological co-morbidities. Clinical Therapeutics, 35(1), A18-A32.

Quinodoz, J. M. (2007). Ler Freud: Guia de leitura da obra de Freud. Porto Alegre: Artes Médicas. 
Reed, Z. E., Micali, N., Bulik, C. M., Smith, G. D., \& Wade, K. H. (2017). Assessing the casual role of adiposity on disordered eating in chilhood, adolescence, and adulhood: a Mendelian randomization analysis. The American Journal of Clinical Nutrition, 106(3), 764-772.

Reppold, C. T., Zanini, D. S., \& Noronha, A. P. P. (2019). In: M. N. Baptista, M. Muniz, C. T. Reppold, C. H. S. S. Nunes, L. F. Carvalho, R. Primi, A. P. P. Noronha, A. G. Seabra, S. M. Wechsler, C. S. Hutz, L. Pasquali (Orgs.). Compêndio de Avaliação Psicológica (pp. 15-28). Petrópolis: Vozes.

Rocha, C., \& Costa, E. (2012). Aspectos psicológicos na obesidade mórbida: Avaliação dos níveis de ansiedade, depressão e do autoconceito em obesos que vão ser submetidos à cirurgia bariátrica. Análise Psicológica, 30(4), 451-466.

Rosa, M. D., \& Domingues, E. (2010). O método na pesquisa psicanalítica de fenômenos sociais e políticos: a utilização da entrevista e da observação. Psicologia \& Sociedade, 22(1), 180-188.

Roudinesco, E. (2002). A família em desordem (A. Telles, Trad.). Rio de Janeiro: Zahar.

Safra, G. (2009). Como elaborar uma tese na perspectiva winnicottiana: facetas ontológicas na produção de conhecimento. CD. Aula ministrada em São Paulo em 17/02/2009. Edições Sorbornost.

Sansone, R. A., \& Sansone, L. A. (2013). The relationship between borderline personality and obesity. Innovations in Clinical Neuroscience, 10(4), 36-40.

Sagui-Henson, S. J., Armstrong, L. M., Mitchell, A. D., Basquin, C. A., \& Levens, S. M. (2020). The effects of parental emotion regulation ability on parenting self-efficacy and child diet. Journal of Child and Family Studies, 29(8), 2290-2302.

Scotton, I. L., Affonso, G., Pessa, R. P., Conceição, E. M., \& Neufeld, C. B. (2019). Aspectos psicológicos em indivíduos com sobrepeso e obesidade. Saúde e Pesquisa, 12(2), 295307.

Segal, H. (1975). Introdução à obrada de Melanie Klein. (Trad. Guimarães, J. C.) Rio de Janeiro, Imago (Trabalho original publicado em 1963). 
Segal, A., Cardeal, M. V., \& Cordás, T. A. (2002). Aspectos psicossociais e psiquiátricos da obesidade. Revista de Psiquiatria Clínica, 29(1), 81-89.

Silva, J. M., \& Dionisio, G. H. (2019). Panorama sobre a obesidade: do viés cultural aos aspectos psíquicos. Revista da SBPH, 22(2), 248-275.

Soifer, R. (1980). Psicodinamismos da família com crianças: Terapia familiar com técnica de jogo (E. F. Alves, Trad.). Petrópolis: Vozes.

Somaraki M., Elib, K., Sorjonend, K., Eke, A., Sandvika, P., \& Nowickaa, P. (2020). Changes in parental feeding practices and preschoolers' food intake following a randomized controlled childhood obesity trial. Apettite, 154, 1-11.

Sousa, P. M. L. (2008). Body-image and obesity in adolescence: a comparative study of social-demographic, psychological, and behavioral aspects. The Spanish Journal of Psychology, 11(2), 551-563.

Stake, R. E. (2011). Pesquisa qualitativa: como as coisas funcionam. Porto Alegre: Penso.

Staudt, A. C. P., \& Wagner, A (2008). Paternidade em tempos de mundança. Psicologia: Teoria e Prática, 10(1), 174-185.

Tamayo, D. T. B., López, J. G. B., Gutiérrez, G. L. V., Rosabal, S. L. \& Tamayo, G. B. (2020). Prevalencia y factores de riesgo de obesidad en adolescentes Policlínico René Vallejo Ortiz. Manzanillo 2016-2017. Multimed, 24(2), 416-433.

Trinca, W. (2002). Considerações sobre um modelo de pesquisa em Psicanálise. Psychê, 6(10), 195-204.

Trinca, W. (2013). Formas compreensivas de investigação psicológica: Procedimento de Desenhos-Estórias e Procedimento de Desenhos de Família com Estórias. São Paulo: Vetor.

Turato, E. R. (2005). Métodos qualitativos e quantitativos na área da saúde: definições, diferenças e seus objetos de pesquisa. Revista de Saúde Pública, 39(3), 507-514.

Younes, S., Rizzotto, M. L. F., \& Araújo, A. C. F. (2017). Itinerário terapêutico de pacientes com obesidade atendidos em serviço de alta complexidade de um hospital universitário. Saúde em Debate, 41(115), 1046-1060. 
Valdanha, E. D., Scorsolini-Comin, F., \& Santos, M. A. (2013). Anorexia nervosa e transmissão psíquica transgeracional. Revista Latinoamericana de Psicopatologia Fundamental, 16(1), 71-88.

Villemor-Amaral, A., \& Cardoso, L. M. (2019). Avaliação da personalidade no Brasil usando métodos projetivos. In: M. N. Baptista, M. Muniz, C. T. Reppold, C. H. S. S. Nunes, L. F. Carvalho, R. Primi, A. P. P. Noronha, A. G. Seabra, S. M. Wechsler, C. S. Hutz, L. Pasquali (Orgs.). Compêndio de Avaliação Psicológica (pp. 475-482). Petrópolis: Vozes.

Villemor-Amaral, A., \& Pianowski, G. (2019). O teste de Rorchach e a personalidade em ação. In: M. N. Baptista, M. Muniz, C. T. Reppold, C. H. S. S. Nunes, L. F. Carvalho, R. Primi, A. P. P. Noronha, A. G. Seabra, S. M. Wechsler, C. S. Hutz, L. Pasquali (Orgs.). Compêndio de Avaliação Psicológica (pp. 541-549). Petrópolis: Vozes.

Westen, S. C., Mitchell, T. B., Mayer-Brown, S., Rawlinson, A. R., Ding, K., \& Janicke, D. M. (2020). Mother and father controlling feeding behaviors and associations with observed mealtime family functioning. Journal of Pediatric Psychology, 44(10), 11741183.

Wong, M. S., Jones-Smith, J. C., Colantuoni, E., Thorpe, R. J., Bleich, S. N., \& Chan, K. S. (2017). The longitudinal association between early childhood obesity and fathers' involvement in caregiving and decision-making. Obesity, 25(10), 1754-1761.

Winnicott, D. W. (1975). O brincar e a realidade. (Trad. J. O. A. Abreu e V. Nobre). Rio Janeiro: Imago Editora Ltda. (Trabalho original publicado em 1971).

Winnicott, D. W. (1994). Transtorno [disorder] Psicossomático. In: C. Winnicott, R. Shepherd \& M. Davis. Explorações psicanalíticas: D.W. Winnicott. (J. O. A. Abreu, trad., pp. 82-93). Porto Alegre: Artes Médicas. (Trabalho original publicado em 1964).

Winnicott, D. W. (1994). O uso de um objeto no contexto de Moisés e o monoteísmo. In: C. Winnicott, R. Shepherd \& M. Davis. Explorações psicanalíticas: D. W. Winnicott. (J. O. A. Abreu, trad., pp. 187-191). Porto Alegre: Artes Médicas. (Trabalho original publicado em 1969).

Winnicott, D. W. (1998). Estabelecimento da relação com a realidade externa. In D. W. Winnicott, Natureza humana (D. Bogomoletz, trad., pp. 120-135). Rio de Janeiro: Imago Editora. (Trabalho original publicado em 1954). 
Winnicott, D. W. (2000). Desenvolvimento emocional primitivo. In: D. W. Winnicott, Textos selecionados: Da pediatria à psicanálise. (D. Bogomoletz, trad.) (2a ed.). Rio Janeiro: Imago. (Trabalho original publicado em 1945)

Winnicott, D. W. (2000). A mente e sua relação com o psicossoma. In: D. W. Winnicott, Textos selecionados: Da pediatria à psicanálise. (D. Bogomoletz, trad., pp. 332-346) ( $2^{\mathrm{a}}$ ed.). Rio Janeiro: Imago. (Trabalho original publicado em 1949).

Winnicott, D. W. (2000). A agressividade em relação ao desenvolvimento emocional. In: D. W. Winnicott, Textos selecionados: Da pediatria à psicanálise. (D. Bogomoletz, trad., pp. 288-304) (2 ed.). Rio Janeiro: Imago. (Trabalho original publicado em 1950).

Winnicott, D. W. (2000). Ansiedade associada à insegurança. In: D. W. Winnicott, Textos selecionados: Da pediatria à psicanálise. (D. Bogomoletz, trad., pp. 163-167) (2a ed.). Rio Janeiro: Imago. (Trabalho original publicado em 1952).

Winnicott, D. W. (2000). A preocupação materna primária. In: D. W. Winnicott, Textos selecionados: Da pediatria à psicanálise. (D. Bogomoletz, trad., pp. 399-405) (2 $2^{\text {e ed.). }}$ Rio Janeiro: Imago. (Trabalho original publicado em 1956).

Winnicott, D. W. (2008). O ambiente e os processos de maturação: estudos sobre a teoria do desenvolvimento emocional. (I. C. S. Ortiz, trad.). Porto Alegre: Artmed. (Trabalho original publicado em 1983).

Winnicott, D. W. (2012). A psicologia da separação. In: D. W. Winnicott, Privação e delinquência (A. Cabral, trad, pp. 149-152). São Paulo: Martins Fontes. (Trabalho original publicado em 1958).

Zeller, M. H., Reiter-Purtill, J., Modi, A. C., Gutzwiller, J., Vannata, K., \& Davies, W. H. (2007). Controlled study of critical parental and family factors in the obesigenic environment. Obesity (Silver Spring), 15(1), 126-136.

Zimerman, D. E. (1999). Fundamentos psicanalíticos: teoria, técnica e clínica - uma abordagem didática. Porto Alegre: Artes Médicas.

Zimerman, D. (2004). Bion: da teoria à prática - Uma leitura didática. Porto Alegre: Artmed, 2004. 
